Growth in Transition:

What We Know, What We Don't, and What We Should

\author{
By: Nauro F. Campos and Fabrizio Coricelli
}

William Davidson Working Paper Number 470

February 2002 


\section{GROWTH IN TRANSITION:}

\section{WHAT WE KNOW, WHAT WE DON'T, AND WHAT WE SHOULD ${ }^{1}$}

\author{
Nauro F. Campos \\ University of Newcastle, \\ CEPR and WDI \\ E-mail: n.f.campos@ncl.ac.uk
}

\author{
Fabrizio Coricelli \\ University of Siena, \\ CEU, ECFIN and CEPR \\ E-mail: coricelli@unisi.it
}

This version: February 2002

\footnotetext{
${ }^{1}$ The authors thank Guillermo Calvo, Richard Easterlin, William Easterly, Randall Filer, Stephen Fries, Thorvaldur Gylfason, Barry Ickes, John McMillan, Gur Ofer, Guillermo Perry, Gérard Roland, Dani Rodrik, Marcelo Selowsky, Robert Solow, Lyn Squire, Joseph Stiglitz, three anonymous referees and seminar participants at the Cairo and Bonn GDN Meetings, and Prague IEA Prague and Portoroz CEPRWDI Portoroz Conferences for comments on earlier versions. We gratefully acknowledge financial support from the Global Development Network. We thank Aurelijus Dabušinskas for alacritous research assistance. The usual disclaimer applies.
} 


\begin{abstract}
This essay surveys macroeconomic issues that marked the transition from centrally planned to market economy in Central and Eastern European and former Soviet Union countries. We first establish a set of stylized facts of the transition so far, namely: (1) output fell, (2) capital shrank, (3) labor moved, (4) trade reoriented, (5) the structure changed, (6) institutions collapsed, and (7) transition costs. We then critically survey the theoretical literature on transition, discussing various explanations for the initial output fall as well as medium term issues, such as optimal speed of transition, disorganization, institutions and sectoral reallocation as a source of output dynamics. Last, we review the empirical literature to assess how well it translates the theoretical models and explains the stylized facts. The essay concludes with a succinct list of suggestions for future research.
\end{abstract}

Keywords: Economic Growth, Transition Economies JEL Classification Codes: E23, O40, P20, P52 


\section{William Davidson Institute Working Paper 470}

\section{Introduction}

When the first signs appeared about ten years ago that the socialist experiment was finally over, surprise and optimism immediately followed. Surprise was caused by the rapid succession of communist regimes collapsing which culminated with the dissolution of the Soviet Union in 1991. Optimism was justifiable. ${ }^{2}$ The removal of the overwhelming apparatus of political control over economic activity could only mean prosperity in the medium term. The Central and Eastern European and former Soviet Union countries were well prepared for rapid take-off: they were industrialized, they had reasonably educated and healthy labor forces, and population growth was minimal. Technology was lagging but with the free flow of information and Western assistance, that could be overcome. Moreover, there was substantial technical progress in the defense sector that, maybe, could spill over the economy, reinforcing optimistic predictions. Some countries (notably Poland) had to tackle macroeconomic imbalances first, but for that economists felt well equipped. Prosperity was, finally, around the corner.

Ten years have passed and the results are mixed, at best. The defining stylized fact of the first ten years of the transition from a centrally planned to a market economy is the massive output fall (see Figure 1). Although the myriad of data problems still prevents the full assessment of its magnitude, very few doubt its occurrence. Reported output fell in every single country of the former Eastern bloc. Indeed, real GDP in 1999 had surpassed its 1989 level in just two of those 25 countries, and in the most severe cases, the observed cumulative output fall was larger than 50 percent of 1989 GDP (EBRD, 2000).

The objective of this paper is to take stock of what happened during the first ten years of the transition from centrally planned to market economy in the Central and Eastern European and former Soviet Union countries, and of the various theories and explanations that have been proposed. This is an ambitious but important task: arguably, the transition is to join the Great Depression as one of the most important economic events of the last century. Like the Great Depression, it will be intensely studied for the years to come, inter alia, because it marks a

\footnotetext{
2 "The fact that transition came with an often large initial decrease in output should be seen as a puzzle. After all, the previous economic system was characterized by a myriad of distortions. One might have expected that removing most of them would lead to a large increase, not a decrease, in output" (Olivier Blanchard, 1997, p. v). Or, "[M]y prognosis was wrong. I did not predict the deep recession that followed; I was too optimistic in my expectations of future growth" (János Kornai, 2000, p. 21).
} 


\section{William Davidson Institute Working Paper 470}

fundamental break in the ways of organizing and going about economic life. Time is ripe to take stock of what we have learned in order to identify more precisely directions for future research.

We chose to frame the discussion that follows in terms of economic growth after 1989. The reason for concentrating on the post-1989 period is the radical structural break that is currently taking place in these economies as the long-run trend is shifting away markedly from that established under communism. "Transition" itself can be thought of as a change in underlying long-run trends. ${ }^{3}$ For present purposes, this break is seen best in the drastic changes (still taking place) in the way savings are mobilized and investment is carried out, in the different ways labor is organized, in how prices are set, and in the full access to Western civilian technology and management practices. We also note that when economists talk about "economic growth," we have in mind growth of per capita income or of productivity over long periods of time. The reader should be made aware that in the literature on transition economies, growth is used in a more literal sense, that is, as referring to the short-run dynamics of GDP per capita or labor productivity.

The paper is organized as follows. The next section offers a descriptive analysis of growth performance in transition countries relative to other regions, and it includes a discussion of available growth accounting results. It goes beyond this decomposition and examines the importance of different factors that have been identified in the cross-country literature as being associated with growth. We summarize these ten years by means of a list of stylized facts of the transition so far namely: (1) output fell, (2) capital shrank, (3) labor moved, (4) trade reoriented, (5) the structure changed, (6) institutions collapsed, and (7) transition costs. In Section 3, we provide a critical survey of the theoretical macrodynamical literature on transition. We discuss the various explanations for the initial output fall as well as medium term issues, such as the optimal speed of transition, disorganization, institutions and sectoral reallocation as a source of output dynamics. Section 4 reviews the empirical literature to assess how well it translates the theoretical models and explains the stylized facts. Section 5 concludes with a number of issues that we believe deserve further attention.

3 Stanley Fischer, Ratna Sahay and Carlos Vegh point out that "a useful way to think about the current growth prospects of the transition economies is to consider them subject to two sets of forces: those arising from the transition and transformation process, and the basic neoclassical determinants of growth. The further along a country is in the transition process, the less weight on the factors that determine the transitional growth rate, and the greater the weight on the standard determinants of growth" (1996a, p.231). 


\section{The Growth Performance of Transition Economies}

The objective of this section is to provide a set of stylized facts that summarizes the developments in the last ten years or so in a manner that is informative for theoretical work. The underlying question is what are the basic facts that a theory of transition should try to explain? After examining the key characteristics of growth before 1989, we highlight the difficulties in establishing the relevant groups of "comparator countries" and, assisted by the theory of economic growth, ${ }^{4}$ set out in search of the stylized facts of the transition so far.

Before proceeding, a caveat about data quality and comparability is needed. These problems are many and are well documented (Kasper Bartholdy, 1997). Socialist statistical offices had a comparative advantage in measuring quantities, and were ill equipped to deal with issues such as price changes (let alone inflation) and unemployment. Moreover, the systemic transformation meant a radical change in incentives from fulfilling plan targets to evading taxes, from over-reporting to under-reporting output. Last, but not least, the initial years of the transition witnessed an extraordinary explosion in size of the informal sector or "hidden" economy (Simon Johnson, Daniel Kaufmann and Andrei Shleifer, 1996; Friedrich Schneider and Dominik Enste, 2000). All these factors should be kept in mind during the following discussion.

\subsection{Before and after: The 1990s as a turning point}

After briefly examining the main features of Soviet economic growth, in this section we discuss the empirical evidence addressing the poor performance of the "Eastern Bloc" as a whole and present growth accounting results that yield a first decomposition of the main reasons for this poor performance. We believe the legacy of socialism is crucial to understand the first ten years of the transition because together with centralizing control, economic growth was an imperative of the socialist system by which its success was to be judged. ${ }^{5}$

\footnotetext{
${ }^{4}$ Robert Barro and Xavier Sala-i-Martin (1995), Phillippe Aghion and Peter Howitt (1998), Steven Durlauf and Danny Quah (1999) and Jonathan Temple (1999) survey the literature on economic growth, and Gur Ofer (1987) surveys the literature on Soviet growth performance.

${ }^{5}$ According to Lenin: "Socialism calls for greater productivity of labor, compared with capitalism and on the basis achieved by capitalism" (cited in Kornai, 1992).
} 


\section{William Davidson Institute Working Paper 470}

What were the main economic characteristics of the socialist system? ${ }^{6}$ Richard Ericsson (1991) summarizes the Soviet-type economy in 9 main characteristics: (1) hierarchical structure of authority, (2) centralized economic planning, (3) commitment to maximal resource utilization, (4) formal rationing through administered allocation in physical terms of producers' goods and services, (5) rigid price control, (6) lack of true money, (7) the lack of legal alternatives to assigned economic relationships, (8) arbitrary control by superiors of the norms and indices of plan assignments, performance evaluation and rewards, and (9) incentives geared towards meeting plan targets.

Economic growth was an imperative of the socialist system. The pattern of economic growth pre-1989 was based on extensive growth, that is, it favored accumulation instead of technological and organizational changes (Ofer, 1987). There seems to be consensus that the extensive growth strategy, achieved by rapid industrialization, worked rather well until the 1960s. ${ }^{7}$ As the first signs of growth slowdown appeared, it became clear that the technological gap with the West was opening up. Two options were available: to create high technology sectors or to foment the diffusion of technology indiscriminately across industries. The leadership, in order to keep tight control, chose the former and channelled resources to the development of military technology. In 1973, the first oil shock gave the Eastern bloc some room to breathe, as the Soviet Union was a major producer. However, western economies responded to the two oil shocks with a boom in energy-saving computer-based technological innovations (Martin Baily and Alok Chakrabarti, 1988). The emergence and rapid diffusion of these technologies is often taken as a major contributor to the end of socialism (Joseph Stiglitz, 1994).

Saul Estrin and Giovanni Urga (1997) document the growth slowdown that defined the last two decades of socialism. They investigate whether or not convergence took place among the socialist economies during the period 1970-1990 (see also Bart van Ark, 2001). They use time-series methods and annual data to assess convergence of GDP among countries of the Eastern bloc as well as between these and Western market economies. Although the finding of no convergence with the West should not come as a surprise, the finding of a marked divergence within bloc is somewhat intriguing given that a declared objective of the Council for Mutual

\footnotetext{
${ }^{6}$ Kornai (1992), Mark Harrisson (1998) and Serguei Guriev and Barry Ickes (2000) discuss the socialist system in detail.

${ }^{7}$ Worked "well" disregarding costs. In addition to rapid natural resources depletion, the gap between the Soviet Union and the United States in GDP per capita was much smaller than in consumption per capita
} 
Economic Assistance (hereafter, CMEA) was the equalization of living standards among its members. To state the obvious, within-bloc divergence meant that, despite the common slowdown, there were marked differences in growth paths. Over 1970-1990, one observes slow growth in Czechoslovakia, rapid growth in Romania and Bulgaria (especially in the 1970s), and cyclical movements in Poland. Turning to the Soviet Republics, one also finds divergence: contrast for example, in Table 1, the performance of Lithuania, Russia and Uzbekhistan to the ones of Turkmenistan and Tajikistan.

Explaining the growth slowdown is harder than documenting it. Growth accounting is helpful in depicting the slowdown. It provides for a decomposition of GDP growth and involves identifying the individual contributions of various factors to overall economic growth. The question that this methodology addresses is how important is factor accumulation relative to improvements in the efficiency with which capital, labor and other factors of production are used. The growth rate of total factor productivity (TFP) is conventionally computed as a residual, as that share of overall growth that cannot be accounted for by increases in quantities of inputs alone. $^{8}$

Tables 1 and 2 present the results of two separate growth accounting exercises. Table 1 presents results from Mark De Broeck and Vincent Koen (2000a) for the former Soviet Union countries. Table 2 present results using the data series for the Central and Eastern European countries from Estrin and Urga (1997). Both cover the period 1970-1997, and use data for labor and capital which were not corrected for hours worked or capacity utilization (thus the reported TFP results after 1990 reflect the impact of the transition). Moreover, in the two sets of results, the shares of labor and capital are assumed to be 0.7 and 0.3 , respectively.

\footnotetext{
(Abram Bergson, 1991).

${ }^{8}$ There are two simplifying assumptions that are commonly made in growth accounting exercises. One is on the form of the production function (a Cobb-Douglas with unitary elasticity of substitution being the norm). The other is on proxying the elasticities of output with respect to labor and capital by the shares of wages and profits in national income, involving the additional assumptions of perfect competition and constant returns to scale (Barro, 1999).
} 
Table 1.

Growth Accounting Results for Former Soviet Union Countries, 1970-1997

\begin{tabular}{|c|c|c|c|c|}
\hline & & Output growth & TFP growth & Factor growth \\
\hline \multirow[t]{4}{*}{ Armenia } & Avg. 1971-97 & 0.9 & -0.8 & 1.7 \\
\hline & Avg. 1971-80 & 6.4 & 2.3 & 4.0 \\
\hline & Avg. 1981-90 & 1.6 & -0.6 & 2.2 \\
\hline & Avg. 1991-97 & -7.9 & -5.6 & -2.2 \\
\hline \multirow[t]{4}{*}{ Azerbaijan } & Avg. 1971-97 & -0.6 & -2.9 & 2.3 \\
\hline & Avg. 1971-80 & 6.1 & 2.6 & 3.5 \\
\hline & Avg. 1981-90 & 0.1 & -2.3 & 2.4 \\
\hline & Avg. 1991-97 & -11.5 & -11.8 & 0.4 \\
\hline \multirow[t]{4}{*}{ Belarus } & Avg. 1971-97 & 2.0 & 0.5 & 1.5 \\
\hline & Avg. 1971-80 & 5.5 & 2.2 & 3.3 \\
\hline & Avg. 1981-90 & 3.1 & 1.5 & 1.6 \\
\hline & Avg. 1991-97 & -4.5 & -3.3 & -1.2 \\
\hline \multirow[t]{4}{*}{ Estonia } & Avg. 1971-97 & 1.1 & 0.2 & 0.9 \\
\hline & Avg. 1971-80 & 3.8 & 1.4 & 2.4 \\
\hline & Avg. 1981-90 & 1.6 & 0.5 & 1.0 \\
\hline & Avg. 1991-97 & -3.4 & -2.2 & -1.2 \\
\hline \multirow[t]{4}{*}{ Georgia } & Avg. 1971-97 & -2.0 & -2.8 & 0.8 \\
\hline & Avg. 1971-80 & 5.3 & 2.7 & 2.6 \\
\hline & Avg. 1981-90 & 0.0 & -1.6 & 1.6 \\
\hline & Avg. 1991-97 & -15.0 & -12.2 & -2.9 \\
\hline \multirow[t]{4}{*}{ Kazakhstan } & Avg. 1971-97 & -0.5 & -2.0 & 1.5 \\
\hline & Avg. 1971-80 & 3.1 & -0.4 & 3.5 \\
\hline & Avg. 1981-90 & 0.4 & -1.6 & 2.0 \\
\hline & Avg. 1991-97 & -6.8 & -4.7 & -2.1 \\
\hline \multirow[t]{4}{*}{ Kyrgyz Rep. } & Avg. 1971-97 & 0.5 & -1.7 & 2.3 \\
\hline & Avg. 1971-80 & 3.3 & -0.5 & 3.8 \\
\hline & Avg. 1981-90 & 3.3 & 0.8 & 2.5 \\
\hline & Avg. 1991-97 & -7.3 & -7.2 & -0.1 \\
\hline \multirow[t]{4}{*}{ Latvia } & Avg. 1971-97 & -0.1 & -0.4 & 0.3 \\
\hline & Avg. 1971-80 & 3.6 & 1.4 & 2.2 \\
\hline & Avg. 1981-90 & 2.3 & 1.3 & 1.0 \\
\hline & Avg. 1991-97 & -8.6 & -5.3 & -3.4 \\
\hline
\end{tabular}


Table 1. (Continued)

Growth Accounting Results for Former Soviet Union Countries, 1970-1997

\begin{tabular}{|c|c|c|c|c|}
\hline & & Output growth & TFP growth & Factor growth \\
\hline \multirow[t]{4}{*}{ Lithuania } & Avg. 1971-97 & 0.8 & -0.3 & 1.1 \\
\hline & Avg. 1971-80 & 2.8 & 0.0 & 2.8 \\
\hline & Avg. 1981-90 & 3.7 & 2.3 & 1.4 \\
\hline & Avg. 1991-97 & -6.3 & -4.5 & -1.8 \\
\hline \multirow[t]{4}{*}{ Moldova } & Avg. 1971-97 & -1.6 & -2.5 & 0.9 \\
\hline & Avg. $1971-80$ & 3.7 & 0.6 & 3.0 \\
\hline & Avg. 1981-90 & 2.1 & 0.9 & 1.2 \\
\hline & Avg. 1991-97 & -14.4 & -11.9 & -2.5 \\
\hline \multirow[t]{4}{*}{ Russia } & Avg. 1971-97 & 0.1 & -1.0 & 1.1 \\
\hline & Avg. 1971-80 & 3.9 & 1.1 & 2.8 \\
\hline & Avg. $1981-90$ & 1.3 & -0.3 & 1.6 \\
\hline & Avg. 1991-97 & -7.0 & -5.4 & -1.6 \\
\hline \multirow[t]{4}{*}{ Tajikistan } & Avg. 1971-97 & -1.9 & -4.4 & 2.5 \\
\hline & Avg. 1971-80 & 4.2 & 0.0 & 4.2 \\
\hline & Avg. 1981-90 & 1.3 & -1.9 & 3.2 \\
\hline & Avg. 1991-97 & -15.2 & -14.3 & -0.9 \\
\hline \multirow[t]{4}{*}{ Turkmenistan } & Avg. 1971-97 & -1.0 & -4.6 & 3.6 \\
\hline & Avg. 1971-80 & 2.4 & -2.2 & 4.6 \\
\hline & Avg. 1981-90 & 1.5 & -2.0 & 3.5 \\
\hline & Avg. 1991-97 & -9.5 & -11.9 & 2.4 \\
\hline \multirow[t]{4}{*}{ Ukraine } & Avg. 1971-97 & -1.6 & -2.4 & 0.8 \\
\hline & Avg. 1971-80 & 2.9 & 0.6 & 2.2 \\
\hline & Avg. 1981-90 & 1.6 & 0.7 & 0.9 \\
\hline & Avg. 1991-97 & -12.5 & -11.2 & -1.3 \\
\hline \multirow[t]{4}{*}{ Uzbekistan } & Avg. 1971-97 & 2.2 & -1.3 & 3.4 \\
\hline & Avg. 1971-80 & 5.0 & 0.4 & 4.6 \\
\hline & Avg. 1981-90 & 2.3 & -1.3 & 3.5 \\
\hline & Avg. 1991-97 & -2.1 & -3.6 & 1.6 \\
\hline \multirow[t]{4}{*}{ AVERAGE } & Avg. 1971-97 & 0.0 & -1.3 & 1.3 \\
\hline & Avg. $1971-80$ & 3.8 & 1.0 & 2.9 \\
\hline & Avg. 1981-90 & 1.5 & 0.0 & 1.5 \\
\hline & Avg. 1991-97 & -7.7 & -6.4 & -1.3 \\
\hline
\end{tabular}

Source: De Broeck and Koen (2000). 
Table 2.

Growth Accounting Results for Central and Eastern European Countries, 1970-1997

\begin{tabular}{|c|c|c|c|c|}
\hline & & Output growth & TFP growth & Factor growth \\
\hline \multirow[t]{4}{*}{ Bulgaria } & Avg. 1971-97 & 1.1 & 0.8 & 0.3 \\
\hline & Avg. 1971-80 & 6.9 & 4.6 & 2.3 \\
\hline & Avg. 1981-90 & 1.9 & 2.1 & -0.2 \\
\hline & Avg. 1991-97 & -8.8 & -6.2 & -2.6 \\
\hline \multirow[t]{4}{*}{ Croatia } & Avg. 1971-95 & 1.1 & 1.1 & 0 \\
\hline & Avg. 1971-80 & 5.7 & 3.3 & 2.4 \\
\hline & Avg. 1981-90 & -0.8 & 0.9 & -1.7 \\
\hline & Avg. 1991-95 & -4.2 & -3.2 & -1.0 \\
\hline \multirow[t]{4}{*}{ Czech Republic } & Avg. 1971-97 & 0.5 & -0.6 & 1.1 \\
\hline & Avg. 1971-80 & 3.4 & 1.7 & 1.7 \\
\hline & Avg. 1981-90 & 0.8 & 0.2 & 0.6 \\
\hline & Avg. 1991-97 & -4.2 & -5.1 & 0.9 \\
\hline \multirow[t]{4}{*}{ Hungary } & Avg. 1971-96 & 2.8 & 2.4 & 0.4 \\
\hline & Avg. 1971-80 & 4.9 & 3.2 & 1.7 \\
\hline & Avg. 1981-90 & 1.1 & 2.1 & -1.0 \\
\hline & Avg. 1991-96 & 1.9 & 1.6 & 0.3 \\
\hline \multirow[t]{4}{*}{ Poland } & Avg. 1971-97 & 2.7 & 0.9 & 1.8 \\
\hline & Avg. 1971-80 & 5.9 & 2.7 & 3.2 \\
\hline & Avg. 1981-90 & 0 & -0.3 & 0.3 \\
\hline & Avg. 1991-97 & 1.8 & 0.1 & 1.7 \\
\hline \multirow[t]{4}{*}{ Romania } & Avg. 1971-97 & 3.1 & 1.9 & 1.2 \\
\hline & Avg. 1971-80 & 9.4 & 5.6 & 3.8 \\
\hline & Avg. 1981-90 & 0.4 & 1.3 & -0.9 \\
\hline & Avg. 1991-97 & -2.4 & -2.4 & 0 \\
\hline \multirow[t]{4}{*}{ Slovak Republic } & Avg. 1971-97 & 2.1 & 0.8 & 1.3 \\
\hline & Avg. 1971-80 & 5.1 & 2.9 & 2.2 \\
\hline & Avg. 1981-90 & 1.5 & 0.8 & 0.7 \\
\hline & Avg. 1991-97 & -1.6 & -2.3 & 0.7 \\
\hline \multirow[t]{4}{*}{ Slovenia } & Avg. 1971-95 & 3.7 & 2.6 & 1.1 \\
\hline & Avg. 1971-80 & 5.7 & 2.7 & 3.0 \\
\hline & Avg. 1981-90 & -0.9 & -0.3 & -0.6 \\
\hline & Avg. 1991-95 & 8.9 & 7.9 & 1.0 \\
\hline
\end{tabular}


Table 2. (Continued)

Growth Accounting Results for Central and Eastern European Countries, 1970-1997

\begin{tabular}{llccc}
\hline AVERAGE & Avg. 1971-95 & 2.1 & 1.2 & 0.9 \\
& Avg. 1971-80 & 5.9 & 3.3 & 2.5 \\
& Avg. 1981-90 & 0.5 & 0.8 & -0.3 \\
& Avg. 1991-95 & -1.1 & -1.2 & 0.1 \\
\hline
\end{tabular}

Note: The authors thank Saul Estrin and Giovanni Urga for generating these results using their data (2000).

One important result from Tables 1 and 2 is the evidence characterizing the extensive growth regime and the exhaustion of its capacities from 1970 onwards. Not surprisingly, the pattern of extensive growth is more manifest for the former Soviet Union than for the Central and Eastern European countries as the average rates of factor growth for the former are substantially higher in all time periods. Although the general pattern of growth slowdown is easy to see, the structural break mentioned earlier is not. The trend reversal can be seen to date in very few countries (namely Poland, Hungary and Slovenia). ${ }^{9}$ It should also be noted that declines in TFP are rather large vis-à-vis the decline in factor accumulation rates, indicating the rapid deterioration of the growth potential of the Soviet-type economy. Recall that this happens despite the increases in non-participation and in open unemployment (Blanchard, 1997), and despite investment falling below replacement levels (particularly, in the early transition years).

A second important result De Broeck and Koen (2000a) establish is that the output fall at the outset of the transition is accounted for by declines in TFP rates. Yet, the year-to-year results referred to above show a "V-shaped" pattern in TFP growth during transition (large initial falls followed by rapid recovery). In order to investigate this issue further, they pply the crosssectoral decomposition of TFP proposed by Andrew Bernard and Charles Jones (1996). This involves separating out the contribution of productivity changes within sectors from that of changes in the sectoral composition to aggregate TFP growth. This second component is of interest as it will be positive if factors are reallocated from lower to higher productivity sectors.

\footnotetext{
${ }^{9}$ After 1989, the slowdown accelerates but it is reverts three or fours years later. These annual results are reported in De Broeck and Koen (2000a, Appendix Table A1).
} 
De Broeck and Koen (2000a) report that this component was negative until the late 1980s and turns positive after that. ${ }^{10}$

Because economic growth was an imperative of the socialist system, the reasons why the extensive growth strategy failed are (and will remain for some time) subject to debate, as they are part of the answer to the difficult question "why did socialism fail?" Two answers are the low productivity rates and the various rigidities in the economic structure, the latter well reflected in the low elasticity of substitution between factors of production (William Easterly and Stanley Fischer, 1995). It should also be noted that the reasons for failure can be identified in every single "growth determinant". Regarding capital, the absence of capital markets in a regime of "investment hunger" reinforced the hiatus between the choice of investment projects and the rates of return on capital. In addition, the plan generated severe restrictions to capital mobility. The industrial structure was tilted towards heavy industry and against light industry. Services were considered, in Marxist terminology, "unproductive". Among heavy industries, defense was the champion, creating an overwhelming burden and responding for the "hyper-militarization" of the Soviet-type economy. With respect to labor, we must recall that not only there was no unemployment under socialism, but also constant excess demand for labor. There was massive labor hoarding to cope, inter alia, with uncertainties in the delivery of inputs (to fulfill plan targets) and in order to maximize the amount of subsidies for the enterprise. The labor force was highly educated, although low morale was pervasive and the incentives for the allocation of talent distorted, all resulting in a low number of hours effectively worked. Last, but not least, the lack of technological progress is often associated with the absence of organizational innovation as there was no entry of new firms and, of course, no competition (Ofer, 1987).

The growth slowdown of the economies of the Eastern Bloc is also useful to throw light on the overall economic conditions at the brink of the collapse, that is circa 1989. This is of great importance for our objectives because one main question the literature on the growth performance of transition economies in the 1990s attempts to answer is the relative importance of initial conditions vis-à-vis that of reforms.

Several countries introduced piecemeal reforms prior to the 1990s, in order to give more independence to enterprise decisions and develop some form of market behavior within the

\footnotetext{
${ }^{10}$ However, "the change in the share effect was small, however, indicating that sectoral input reallocation did not have a major impact on productivity" (De Broeck and Koen, 2000a, p. 20).
} 


\section{William Davidson Institute Working Paper 470}

planned economy. Although there is a consensus on the negative impact of such half-hearted reforms prior to the full-fledged market reforms of the 1990s, it is becoming increasingly apparent that countries that experienced such partial reforms are better positioned now along the path of a more efficient market economy. This observation appears rather natural if one views a minimal structure of market institutions and some experience with market oriented decisions as a precondition for the success of market reforms. The same effects of liberalization policies implemented in the 1990s were likely affected by initial conditions. Countries with less favorable initial conditions were more constrained in the reform process and thus followed a less radical reform path. At the same time, less favourable initial conditions might have adversely affected output performance. As a result, one would observe a positive correlation between reforms and output performance even though the ultimate cause of both reforms and output performance was the set of initial conditions.

One way of gauging the role of initial conditions in a comprehensive manner is to use the principal components technique. Within the set of initial conditions we considered (i) measures of initial distortions, associated both to the structure of the economy (namely the degree of overindustrialization), and to policy induced distortions, such as the premium of the black market exchange rate over the official exchange rate; (ii) "natural" characteristics, such as the physical distance from Western European markets, and the endowment of natural resources; (iii) weight of the inheritance from the previous regime, measured by the time span spent under central planning; and (iv) the degree of development of market mechanisms, albeit primitive. This indicator of presence of some forms of markets is measured by the degree of price liberalization prior to market reforms. We consider this indicator as one of the critical initial conditions. Indeed, our prior is that full-fledged market reforms can bring about a positive impact on growth when the system has a minimal structure that can lead to a positive response of the economy to the "institutional" shock represented by the implementation of liberalization and market reforms. Lacking such minimal structure there is the risk that liberalization and reforms can lead to output decline because of "disorganization" effects (Olivier Blanchard and Michael Kremer, 1997), or because of the development of dysfunctional institutions (Guillermo Calvo and Fabrizio Coricelli, 1996, Coricelli, 1998), such as corruption, barter, and payment arrears.

More specifically, the initial conditions considered are (Table 3): dependence from CMEA trade, a measure of repressed inflation, over-industrialization, the premium of black 
market over official exchange rates, the number of years spent under communism, the distance from Düsseldorf, the share of population living in urban areas, initial income per capita, rate of growth of real output in the five year period preceding reforms, the presence of a national state, or of a federation of states or of breaking-away states. All these variables are meant to reflect initial distortions and imbalances inherited from the previous regime. We also include the value of the price liberalization indicator in the pre-reform period (from Martha De Melo, Denizer Cevdet, Alan Gelb and Stoyan Tenev, 1997). Although simplistic, this variable may signal the conditions of each country in terms of the presence of a minimal set of market mechanisms at the start of full-fledged reforms. It largely reflects the half-hearted attempts during the central planning of introducing some independence in economic decisions by firms and some form of market mechanisms (partial liberalization of prices for instance). Coricelli (1998) and Peter Murrell (1995) have argued that these rudimentary forms of market mechanisms may have played a crucial role in determining performance in the post-reform period.

We use the method of principal components to isolate a limited number of vectors of significant initial conditions (see EBRD, 1999, for a similar approach). The first two principal components explain about 80 percent of the variance. The first component attributes a large negative weight to initial liberalization, and large positive weight to initial distortions, such as repressed inflation, dependence on CMEA trade, black market premium, distance from Düsseldorf and years spent under communist regime. Thus, a positive coefficient on this variable in growth regressions would imply the predominance of the effects of initial distortions, while a negative coefficient implies the predominant role of initial market liberalization. The second component attributes large weights to initial income per capita and the degree of urbanization. This result is important because it serves as a note of caution to the existing literature in its pervasive use of initial income as a general proxy for initial conditions. 
William Davidson Institute Working Paper 470

Table 3

Initial conditions using principal components

\section{First Principal Component Second Principal Component}

$\begin{array}{lcc}\text { LIIni } & -0.598 & 0.043 \\ \text { CMEA } & 0.751 & 0.315 \\ \text { RepInf } & 0.823 & 0.109 \\ \text { BMkt } & 0.940 & 0.137 \\ \text { OverInd } & -0.352 & 0.383 \\ \text { State } & -0.796 & -0.397 \\ \text { StateI } & -0.558 & -0.562 \\ \text { StateF } & -0.478 & 0.330 \\ \text { TCOMM } & 0.902 & 0.019 \\ \text { DIST } & 0.771 & -0.423 \\ \text { YpC89 } & -0.264 & 0.859 \\ \text { Urban } & -0.300 & 0.803 \\ \text { GrIni } & -0.190 & -0.428 \\ \text { NatRes } & 0.474 & -0.147\end{array}$

LIIni=Internal liberalization index in 1989;

CMEA=Share of CMEA trade in 1990 over GDP;

RepInf=Repressed inflation during 1987-90 (DDGT, 1997);

$\mathrm{Bmkt}=$ exchange rate black market premium;

OverInd=Industrial distortion measure (used in Berg et al.1999);

State $=0$ for no own State prior to transition, 1 own State within larger State, 2 own independent State;

StateI=dummy $=1$ if independent State before transition;

StateF=dummy 1 if main state in federation state before transition;

TCOMM=time under Communism;

DIST=distance from Dusseldorf (in km);

YpC89=real GDP per capita in 1989;

Urban $=\%$ of population in urban areas in 1990;

GrIni=growth of GDP per capita during 1985-89;

NatRes=Natural resource endowment according to DDGT(1997), 0="poor", 1="moderate", 2="rich".

Source: Authors' calculations. 
In summary, growth rates in the Eastern bloc have declined uninterruptedly from the 1960s onwards. This slowdown has contributed significantly to the collapse of the socialist system. In the 1990s we see the deepening of this general trend in most countries and the reversal of it (a structural break) in few others. In our analysis of initial conditions, we find that initial income is an inadequate proxy and studies that use only this variable are likely to under-estimate the role of initial condition vis-à-vis other factors such as reform intensity. We now turn to the stylized facts of the transition years, of which the output fall is the first and foremost.

\subsection{Outpul fell}

As already noted, the defining stylized fact of the first ten years of the transition from a centrally planned to a market economy is the massive output fall. Output fell in every single country, with no exceptions, and it took longer than initially expected to recover. Indeed, real GDP in 1999 surpassed its 1989 level in just two of the 25 economies in Central and Eastern Europe and former Soviet Union (EBRD, 2000). Figure 1 has annual GDP growth rates. It clearly shows the massive fall in output. It also shows that the countries of Eastern Europe experienced output declines that turned out to be much smaller than the ones observed, at a later date, among the Commonwealth of Independent States (hereafter CIS) economies. We discuss each of these issues in turn. ${ }^{11}$

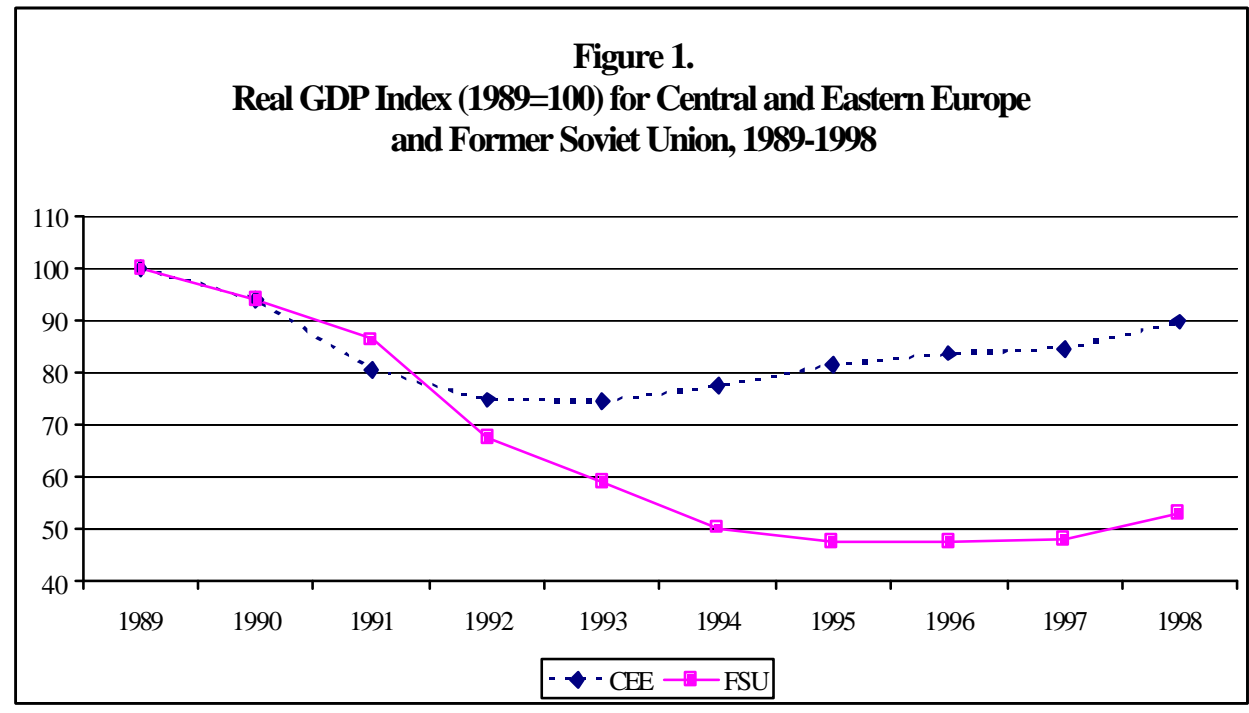

\footnotetext{
${ }^{11}$ In the next section we examine the various explanations that have been offered so far to the output fall.
} 


\section{William Davidson Institute Working Paper 470}

The output fall complicates comparative analysis. We are usually interested in learning about how do events in transition economies stack against countries at similar levels of development or per capita income. One difficulty in identifying which countries are "at similar levels of development" is that while the transition economies started out clustered in the uppermiddle income group ${ }^{12}$, ten years later they are found widely spread over the rank of countries (by their level of development). In other words, the comparator countries change drastically over these first ten years: while in 1989 most transition economies were classified in the upper-middle income group, in 1998 very few remain in that category. This can be fully grasped if we name the "new neighbors" of the transition economies. ${ }^{13}$ Among transition countries, Tajikistan and the Kyrgyz Republic have the lowest GNP per capita in 1998 (followed by Moldova), while Slovenia has the highest (followed by the Czech Republic and Croatia, respectively). The median transition economy is Kazakhstan. Bangladesh is the developing country with the same GNP per capita in 1998 as Tajikistan and the Kyrgyz Republic. Haiti and Mauritania are the countries with approximately the same GNP per capita in 1998 as Moldova. At the other extreme of this distribution, the country immediately above Slovenia is Portugal, ${ }^{14}$ and the one immediately below is Argentina. The Czech Republic ranks between Uruguay and Chile, while Croatia ranks between Brazil and Hungary.

The dispersion in the transition group has increased substantially since 1989 and this list of countries in close positions helps to underline the difficulties in establishing the relevant comparison group of countries at similar levels of development. ${ }^{15}$ Most of the former Soviet Union countries end this period as low income or lower-middle income, while the majority of the

\footnotetext{
${ }^{12}$ The World Bank ranks countries by their level of economic development, using as criterion (1998) GNP per capita (exchange rates conversion). "The groups are: low-income, $\$ 760$ or less; lower-middleincome, \$761-\$3,030; upper-middle-income, \$3,031-\$9,630; and high-income: \$9,361 or more" (World Bank, 1999/2000 World Development Report, p. 291).

${ }^{13}$ The source is the $1999 / 2000$ World Development Report. Data availability impedes to base this analysis upon PPP per capita GNP figures.

${ }^{14}$ According to the 1999/2000 World Development Report, Slovenia is the only "high income" country in this sample of 25 transition economies.

${ }^{15}$ As for levels of development, one can argue that income per capita alone does not do justice to the years of effort to improve social conditions (e.g., education and health) that characterized the socialist regimes. UNDP (1998) ranks 174 countries according to their "human development index" (which reflects, in addition to income, life expectancy and education attainment.) Our sample of 25 transition economies stretches from the $37^{\text {th }}$ (Slovenia, immediately preceded by Argentina and followed by Uruguay) to the $118^{\text {th }}$ place (Tajikistan, immediately preceded by Cape Verde and followed by Honduras). The median country is Macedonia (in $80^{\text {th }}$ place), immediately preceded by Lithuania and followed by Syria. In sum, the dispersion seems to have increased also abng these lines.
} 
Central and Eastern Europeans (and Baltic) countries in the late 1990s are classified as uppermiddle income economies.

A major caveat in assessing the depth of the output fall is that it refers to official estimates and thus ignores the shadow economy or informal sector. The latter has grown very rapidly in the early transition years and the way researchers have measured it is using electricity consumption as a more encompassing measure of economic activity. It is reassuring to note that the output fall also obtains using an electricity consumption index (Johnson, Kaufmann and Shleifer, 1997). For example, in its lowest point the GDP index of Visegrad countries was 85 per cent of its 1990 GDP level while the corresponding value of the electricity consumption index was 90 per cent. At the other extreme, the trough values of GDP and electricity consumption indexes for the Central Asian countries were only 46 and 62 per cent, respectively. In most countries, total activity seems to have declined less than what the official figures suggest. Yet the output fall obtains irrespective of the measure chosen. It is important, however, to keep in mind that consumption fell less than output.

\subsection{Capital shrank}

Compared to advanced market economies, investment under central planning was high and inefficient. Voluntary savings during the transition, carried out by households and private enterprises in a market economy, would tend to be lower than forced centralized savings under planning. Thus, the expectation was that market forces would improve investment efficiency but sustain investment rates at lower levels than under central planning. On the other hand, the process of economic transformation would require additional investment to account for restructuring and for the upgrading of outdated products and production processes. A lot was expected from Foreign Direct Investment (FDI). Foreign capital could not only bridge the possible medium-term gap between domestic savings and investment needs but also help in restructuring and modernizing transition economies. In order to trace the actual behavior of domestic investment and foreign participation during the transition, in what follows we analyze data on gross domestic fixed investment (GFDI) as a share of GDP as well as some aggregate FDI indicators. ${ }^{16}$

\footnotetext{
${ }^{16}$ Data availability still prevents a full assessment of the role of natural capital (Thorvaldur Gylfason, 2001). We discuss human capital in the next sub-section.
} 
Table 4

Aggregate Investment as Percentage of GDP

Regional Averages: 1990-1998

\begin{tabular}{lccccccccc}
\hline & 1990 & 1991 & 1992 & 1993 & 1994 & 1995 & 1996 & 1997 & 1998 \\
& & & & & & & & & \\
BALTICS & 24.78 & 16.52 & 18.40 & 20.43 & 21.66 & 21.38 & 22.62 & 23.67 & 24.51 \\
BALKAN & 18.49 & 13.23 & 14.94 & 14.88 & 15.68 & 16.99 & 19.17 & 18.30 & 18.63 \\
VISEGRAD & 24.01 & 22.48 & 22.99 & 22.74 & 23.20 & 23.92 & 26.72 & 27.77 & 28.36 \\
ASIA & 28.74 & 20.44 & 18.38 & 15.50 & 17.21 & 17.34 & 20.37 & 18.66 & 19.05 \\
BUR & 24.64 & 21.85 & 25.51 & 26.18 & 26.19 & 23.07 & 21.22 & 21.20 & 20.95 \\
& & & & & & & & & \\
CEEB & 22.43 & 17.41 & 18.78 & 19.35 & 20.18 & 20.76 & 22.84 & 23.25 & 23.83 \\
CIS & 25.92 & 21.58 & 21.68 & 22.37 & 22.05 & 21.84 & 22.30 & 19.87 & 19.41 \\
& & & & & & & & & \\
\hline
\end{tabular}

Notes: Authors' calculations using 2000 World Development Indicators data. See text for definition of regional groups.

Table 4 shows investment rates between 1990 and 1998. ${ }^{17}$ With respect to aggregate investment activity during transition, two main observations should be made. First, that investment has fallen more than GDP, and thus investment rates declined and, second, that the latter decline was smaller than is usually the case in demand driven recessions in advanced market economies ((Jacek Rostowski, 1997; Stanislaw Gomulka, 1998). Table 4 shows that investment ratios declined sharply at the beginning of the transition. In the case of CEEB, this decline was 32 per cent between 1989 and 1991, the trough year. Investment rates have recovered and and reached more than 80 per cent of the 1989 level in 1998. The decline was more severe in the CIS countries. Not only the latter started with higher investment rates, but as late as 1998 there are no clear signs of a recovery.

Although a broadly similar pattern in the development of investment to GDP ratio can be observed in all five subgroups in the region, three additional comments are noteworthy. First, the poor performance of the CIS average seems to be driven by the ASIA group, while the latter's average is dominated by war affected countries of the Caucasus region. Indeed, it seems that for

\footnotetext{
${ }^{17}$ We divided the sample in five groups for exposition purposes. The transition countries in ASIA are Armenia, Azerbaijan, Georgia, Kazakhstan, Kyrgyztan, Tajikistan, Turkmenistan and Uzbekistan. The BALKAN countries are Albania, Bulgaria, Croatia, Macedonia, Moldova and Romania. The BALTIC countries are Estonia, Latvia and Lithuania. The group called BUR comprises Belarus, Ukraine and Russia. The VISEGRAD countries are the Czech Republic, Hungary, Poland, Slovakia and Slovenia. CEEB stands for Central and Eastern European and Baltic countries and represents the sum of the
} 
BUR the decline in the rate of fixed investment was very much in line to that of CEEB countries. The investment rate decreased during 1989-91 and then had a very weak and tentative recovery. In contrast, the pattern of investment behaviour in Asia was much different, as the ratio dropped drastically from 1990 to 1994 and only then tentatively started to stabilize. A second remark is that the Vysegrad group stands out for the relative mildness of the initial decline in the rate of investment. And third, Belarus, Ukraine and Russia experienced a reversal in the series from an upward to a downward trend in 1994. This reversal took place after three years of stability in the BUR investment rate during 1992-94 and sharply contrasted with the behaviour of investment to GDP ratios in other subgroups.

How do gross domestic investment rates of transition economies compare to the average investment rates in countries at similar income levels? Investment rates in transition economies range from 14 to 28 percent of GDP, and for 1998 only three out of our five groups have averages above 20 percent. The often heard concern about these figures being too low must be echoed here (and particularly so regarding the countries in the BALKAN and ASIA groups.) In 1995, investment rates averaged 30 percent for low-income economies, 23 percent for both lower-middle economies and upper-middle economies, and 19 percent for high-income economies. ${ }^{18}$ Given the current level of development of most transition economies, their investment rates are indeed low.

BALTIC, BALKAN and VISEGRAD sub-groups.

${ }^{18}$ Source is World Bank, 1999/2000 World Development Report. 
Table 5

Foreign Direct Investment in Transition Economies

$\begin{array}{cccc}\text { Cumulative FDI } & \begin{array}{c}\text { Cumulative FDI } \\ \text { inflows, 1988-99 }\end{array} & \begin{array}{c}\text { Cumulative FDI } \\ \text { inflows as \% of inflows per capita, }\end{array} & \begin{array}{c}\text { Average FDI inflow as \% } \\ \text { of gross domestic }\end{array} \\ \text { (Billion dollars) } & \text { GDP, 1988-99 } & 1988-99 \text { (dollars) } & \text { investment, 1997-99 }\end{array}$

$\begin{array}{lcccc}\text { BALTIC } & 2.10 & 30.27 & 923.67 & 27.00 \\ \text { BALKANS } & 2.07 & 16.85 & 277.50 & 21.40 \\ \text { VISEGRAD } & 14.41 & 22.30 & 1122.80 & 13.40 \\ \text { ASIA } & 1.73 & 32.35 & 183.00 & 39.28 \\ \text { BUR } & 8.17 & 9.37 & 91.00 & 7.33 \\ & & & & \\ \text { CEEB } & 6.19 & 23.14 & 774.66 & 20.60 \\ \text { CIS } & 4.95 & 20.85 & 137.00 & 23.31\end{array}$

Notes: Authors' calculations using data from the United Nations Economic Commission for Europe's Economic Survey of Europe (2001, no.1). See text for definition of regional groups.

Since the start of transition, FDI inflows have been rising constantly but their magnitude and importance remain highly unequal among country subgroups. ${ }^{19}$ Table 5 shows four different aspects of the performance of Foreign Direct Investment (FDI) in transition economies. These are: cumulative FDI inflows, cumulative FDI inflows as a share of GDP, cumulative FDI inflows per capita and the average FDI inflows as share of domestic gross fixed capital formation. Interestingly, each indicator shows a slightly different picture. For example, in terms of cumulative FDI inflows, the considerable differences between CEEB and CIS countries (the FDI stock in the average CEEB country is larger than in the average CIS country) pale with respect to differences at the level of sub-groups. FDI is highly concentrated: the VISEGRAD and BUR (in this case, predominantly Russia) groups account for about $80 \%$ of the total stock of FDI in transition economies.

If we examine cumulative FDI inflows over 1988-1999 as a share of GDP, the conclusions are different. Although this share is still higher in CEEB than in CIS countries, the BALTIC and ASIA groups, respectively, are the ones driving up these averages. In the case of ASIA, we should mention that for Azerbaijan, the ratio of cumulative FDI inflows over GDP is

\footnotetext{
${ }^{19}$ Nauro Campos and Yuko Kinoshita (2001) provide a full discussion of growth impacts of FDI in transition.
} 
above $90 \%$. This ratio is also very high (about $45 \%$ ) for Kazakhstan. For the Baltic countries, this ratio ranges from about $38 \%$ for Estonia to about $20 \%$ in the case of Lithuania. The measure of net FDI inflows relative to countries' GDP has been somewhat more dynamic since 1994 and hints that FDI is rapidly gaining importance not only in the Baltic countries but also in Asia. For this latter group, the average rate of foreign direct investment went up from a mere 1 percent in 1994 to almost 35 per cent of GDP in 1999. It should be noted that natural resources (oil and natural gas) are one of the most important determinants of such high FDI flows to ASIA.

It is in terms of cumulative per capita FDI inflows that the gap between the CIS and CEEB is wider. The Vysegrad countries have maintained a leading position, with cumulative FDI inflow per capita reaching about $\$ 1200$ by 1999 . Balkan, BUR, and Asia groups remain far behind as the amount of cumulative per capita FDI was just $\$ 300$ or less, while $\$ 950$ stock of per capita FDI in the Baltic countries place them in between these two extremes.

The FDI to domestic investment ratio shows a relatively similar picture to that implied by the FDI-to-GDP ratios. The share of FDI in domestic investment has been rising in all countries except in the Vysegrad group, where the share has been relatively flat. Considering the average over 1997-1999, notice the very high average for the ASIA group. Azerbaijan, Kazakhstan, Georgia and Armenia all show FDI to domestic investment ratios of at least $45 \%$.

In summary, capital accumulation slowed down considerably during the transition period. Capital shrank. In the CEEB countries, investment rates have already shown a timid recovery, while in the CIS countries the declined does not seem to have been reversed yet. FDI has played a substantial role in transition economies particularly for its role as carrier of new technologies, but it has been concentrated in very few countries and unable by itself to reverse the trends in aggregate investment.

\subsection{Labor moved}

The previous section tried to answer what happened to physical capital during the transition. This section addresses the question of what happened to labor during the transition. The difference in answers is telling in terms of the needs for future research. It seems we know much less about what happened to the stock of capital from the communist period than about increases to that stock during the transition period. For instance, we know quite a bit about domestic and foreign 


\section{William Davidson Institute Working Paper 470}

direct investment. But we do not know much about what happened to communist capital (did it depreciate very fast? How much of it was reallocated to the emerging private and informal sectors?) On the other hand, when it comes to labor, we know quite a bit of what happened in terms of participation rates and labor markets flows, but we know little about how the huge stocks of human capital accumulated under communism were valued during the transition. ${ }^{20}$

Labor is a fundamental determinant of growth, because of the sheer size of the labor force as well as the quality of the labor input (human capital). As for the former, the literature tends to focus on population size and growth, under the assumption that differences in participation rates and demographic structure are negligible over the long run. The conventional wisdom, that these economies have quite low rates of population growth, is confirmed and marks one of the indisputable differences between economies in transition and the rest of the developing countries. The average annual population growth rate across transition economies is 0.21 percent. $^{21}$ The same average in 1990-1998 is 2.0 percent for low-income economies, 1.4 percent for lower middle-income economies, 1.6 percent for upper middle-income economies, and 0.7 percent for high-income economies. ${ }^{22}$ Although average population growth is low, there are exceptions: Turkmenistan, Uzbekistan, and Tajikistan all show average annual population growth rates well above 2 percent (Armenia follows with a 1.29 percent average).

An important aspect of labor developments in transition is the change in participation rates (Tito Boeri, 2000). Participation rates were relatively high under socialism, in particular female participation rates. The initial output shock was followed by a drastic adjustment in this regard and CEEB and CIS averages are similar: declines in participation rates of approximately 3 and 2.5 percentage points, respectively, in the fist five years of the transition. There is one exception: Romania shows an increase in participation rates between 1990 and 1995 (from 68 to 75 percent). This contributes to the BALKAN group showing the lowest average: a decline of about 0.5 percentage points. On the other extreme, the highest average changes in participation rates in the first five years are for the Visegrad countries (decline of 5.8 percentage points). Also note that the average in Belarus, Russia and Ukraine is above that of the Baltic countries (during

\footnotetext{
${ }^{20}$ Jan Švejnar (1999) and Randall Filer, Thorvaldur Gylfason, Stepan Jurajda and Janet Mitchell (2000) survey this literature.

21 These low rates also reflect the demographic situation in the transition economies, where the increasing dependency ratios are usually thought of as having negative fiscal consequences. For a discussion, see Coricelli (1997).

${ }^{22}$ The source is World Bank, 1999/2000 World Development Report.
} 
the period 1990 to 1995). This is particularly interesting in light of the fact that empirical research strongly suggests that in BUR countries labour market adjustment took the form of delayed payments or wage arrears (see Hartmut Lehmann, Jonathan Wadsworth and Alessandro Acquisti, 1999). In a nutshell, there was a significant increase in flows out of the labour force that helps us start to characterise as a stylized fact of the transition that "labour moved."

Another important aspect of labor market adjustment was through unemployment. As noted, a characteristic of the socialist economy was the excess demand for labour (Kornai, 1992). Unemployment rates during the transition process, therefore, grew very rapidly but from a low starting level. Table 6 shows registered unemployment rates. $^{23}$ The trend of increasing unemployment rates is clear. One first noteworthy observation is that unemployment rates increased much faster in the Central and Eastern European countries than in the CIS countries. It is worrisome that it has reached double-digit rates very early (1993) and, ever more worrisome, that these rates have stayed above $10 \%$ until the end of the decade.

Table 6

Registered Unemployment Rates

Regional Averages: 1990-1999

\begin{tabular}{lrrrrrrrrrr}
\hline & 1990 & 1991 & 1992 & 1993 & 1994 & 1995 & 1996 & 1997 & 1998 & 1999 \\
& & & & & & & & & & \\
BALTIC & 0.55 & 0.80 & 2.97 & 6.57 & 9.37 & 15.13 & 15.27 & 12.87 & 12.40 & 13.60 \\
BALKAN & 7.80 & 9.23 & 15.52 & 16.58 & 14.92 & 14.97 & 13.28 & 13.90 & 14.70 & 15.58 \\
VISEGRAD & 2.55 & 8.28 & 8.98 & 11.06 & 10.72 & 9.70 & 9.34 & 8.42 & 9.78 & 11.20 \\
ASIA & n.a. & 0.44 & 4.18 & 4.45 & 4.57 & 5.76 & 6.57 & 7.29 & 8.80 & 9.48 \\
BUR & n.a. & 0.05 & 2.00 & 2.57 & 3.40 & 4.07 & 5.03 & 5.43 & 6.43 & 6.03 \\
CEEB & & & & & & & & & & \\
CIS & n.a. & 0.10 & 9.15 & 11.40 & 11.67 & 13.27 & 12.63 & 11.73 & 12.29 & 13.46 \\
& & & & & & & & & &
\end{tabular}

Notes: Authors' calculations using EBRD (2000) data. See text for definition of regional groups. n.a. indicates data not available.

\footnotetext{
${ }^{23}$ Tito Boeri and Katherine Terrell (2002) discuss the problems with this measure with emphasis on the role of changing institutional features.
} 


\section{William Davidson Institute Working Paper 470}

Table 6 also shows the breakdown of average registered unemployment rates across the five sub-groups. Starting with the former Soviet Union countries, it is important to mention that although the BUR averages are consistently below those of the ASIA group, it conceals the fact that Russian unemployment figures have been four times larger than those for Belarus or Ukraine, throughout. The ASIA average is kept lower thanks to the Central Asian countries that show average rates much lower than those for the Caucasus countries. Now turning to the CEEB sub-groups, note that the average rates for the Balkan countries peak early on and stay high throughout. In this group, we have Macedonia for example with registered unemployment rates never below 18 percent (and peaking at almost 38\% in 1997). It is also remarkable how the behavior of unemployment rates in the Baltic countries resemble much more those in Central and Eastern Europe than those in the CIS. Finally, note that in terms of unemployment rates in the Visegrad countries, the Czech figures are the lowest ones in all years but 1999, when Slovenian rates become the lowest rates in this group (at 7.4\%).

Let us now turn to the issue of human capital in transition. Conventional wisdom holds that if there is one area where the countries of Eastern Europe and former Soviet Union are well served it is with respect to their stocks of human capital. Most human capital indicators (e.g., gross or net enrollments, average years of schooling, and literacy rates) tend to be better in these countries than in the OECD (Robert Barro and Jong-Wha Lee, 2001). Yet recent research shows that not all is well in this front. Boeri (2000) highlights the fact that skills acquired under communism are overly specialized and therefore not easily transferable. He exemplifies by noting that secondary education in Poland offered more than 700 specializations, while the (West) German system offered less than 20. Another way of looking at potential problems in this respect is to consider that there are "too many rocket scientists, too few marketing experts" (Nauro Campos and Aurelijus Dabušinskas, 2001). In other words, despite the high level of educational attainment of the average worker, the composition of the stock of human capital (in terms of the mix of occupations) has proven inadequate to the needs of a modern market economy. $^{24}$

Table 7 reveals a worrisome trend: secondary school gross enrollment ratios not only show considerable variation, but also in many countries have declined since 1990. In particular,

\footnotetext{
${ }^{24}$ Other studies on this topic are Klara Sabirianova (2000) and Nauro Campos and Dana Žlabkova (2001). These studies concur in that at least $30 \%$ of all employed workers changed occupation in the early years of the transition in as different countries as Estonia, Russia and Hungary.
} 
the range of these ratios fell by five percentage points in the first five years alone. This decline can also be seen using different data (on average years of schooling) from Barro and Lee (2001). Note, however, that only the ASIA group shows sustained decline. Although these figures remain high by international standards, ${ }^{25}$ such a contraction is impressive.

\begin{tabular}{|c|c|c|c|c|c|c|c|c|c|}
\hline \multicolumn{10}{|c|}{$\begin{array}{c}\text { Table } 7 \\
\text { Gross School Enrollment Rates (Basic Education) } \\
\text { Regional Averages: 1990-1998 }\end{array}$} \\
\hline & 1990 & 1991 & 1992 & 1993 & 1994 & 1995 & 1996 & 1997 & 1998 \\
\hline BALTIC & 94.70 & 93.43 & 91.57 & 90.70 & 90.73 & 91.53 & 92.20 & 93.30 & 94.00 \\
\hline BALKAN & 90.65 & 89.20 & 86.95 & 87.53 & 87.82 & 88.24 & 89.60 & 93.95 & 94.60 \\
\hline VISEGRAD & 97.68 & 97.70 & 97.76 & 97.62 & 97.36 & 97.46 & 97.80 & 97.94 & 97.40 \\
\hline ASIA & 92.96 & 91.66 & 90.58 & 88.35 & 87.96 & 86.80 & 86.69 & 86.83 & 87.88 \\
\hline BUR & 92.80 & 91.93 & 91.53 & 90.87 & 90.83 & 91.13 & 90.90 & 90.73 & 91.53 \\
\hline CEEB & 94.34 & 93.44 & 92.09 & 91.95 & 91.97 & 92.41 & 93.20 & 95.06 & 95.33 \\
\hline CIS & 92.88 & 91.80 & 91.05 & 89.61 & 89.40 & 88.97 & 88.79 & 88.78 & 89.71 \\
\hline
\end{tabular}

Notes: Authors' calculations using UNICEF's MONEE data. See text for definition of regional groups.

In summary, we think it is correct to say that during the transition process, labor moved. It did not move in the most obvious way, that is, geographically. Over space, labor mobility in transition economies remains extremely low because of, inter alia, distortions in the housing market (Tito Boeri and Christopher Flinn, 1999). Yet workers moved: (a) in large numbers from employed in 1988 to inactivity or unemployed at the end of the 1990s; (b) in large numbers from the state sector to the private sector (this is particularly true in the CEEB countries, see Boeri, 2000); and (c) workers have changed occupation in unprecedented scale.

\footnotetext{
${ }^{25}$ The 1997 World Development Report reports that, in 1993, this ratio for middle-income economies was 63, and 97 for high-income economies (Table 7, pp. 226-227).
} 


\section{William Davidson Institute Working Paper 470}

\subsection{Trade re-oriented}

There are at least two good reasons for studying foreign trade when searching for the stylized facts of the transition. The first is to investigate whether or not the recessionary impact of transition affected foreign trade, and if so, whether the dynamics of trade exhibits a similar pattern. The proposition about the reverse link, that the collapse of CMEA deepened the output fall and that successful trade performance has helped to cope with the fall, reinforces the importance of trade dynamics in the process of transition (Peter Christoffersen and Peter Doyle, 1998). A second reason arises from the expectation that market forces would change the trade patterns of transition countries by reorienting trade towards western markets. ${ }^{26}$ After ten years of transition, one should ask whether foreign trade data indicate that such redirection has indeed taken place. In this section, our focus is on three foreign trade dimensions: trade volumes, trade patterns and openness (trade-to-GDP ratio). ${ }^{27}$

The data support the proposition that the level of foreign trade in transition countries has followed a decline and (partial) recovery pattern. Unweighted averages of export indexes indicate a very strong initial decline and partial recovery in foreign trade for both CEEB and CIS countries. CEEB exports declined by 62 per cent since the start of transition to reach its lowest point in 1993, and then rose up to 71 per cent of 1990 exports level in 1998. CIS exports reached their lowest level a year later, in 1994, but the drop in CIS trade was much more pronounced. Although the CIS exports did show clear signs of recovery since, exports declined again in 1998, this time due to the crisis in Russia. In 1998 CIS exports were about 30 per cent higher than in the trough year (1994) but represented only 15 per cent of 1990 exports.

As for trade redirection, Table 8 shows that the share of industrial countries has increased dramatically in the exports of CEEB and CIS, as well as in all the subgroups of transition economies. The percentage of exports to industrial countries from the CEEB started out twice as high as this share from CIS countries and end up the period three times as high. The share of

\footnotetext{
${ }^{26}$ Robert Baldwin (1994), Paul Brenton and Daniel Gros (1997), Bartlomiej Kaminski, Zhen Wang and Alan Winters (1996) and Mathilde Maurel and Guillaume Cheikbossian (1997) discuss trade reorientation in transition.

${ }^{27}$ The trade data of the FSU countries (Baltic and CIS) are taken from Misha Belkindas and Olga Ivanova (1995) for 1990-1994 period and from the IMF Direction of Trade Statistics (DOTS) for years 1994 1998. The inclusion of year 1994 in both series serves to evaluate using different data sources. For the non-FSU transition economies data are taken from the IMF DOTS. Trade volumes are measured in current US dollars. Trade data in constant US dollars as well as trade-to-GDP ratios are found in the World Bank's World Development Indicators.
} 


\section{William Davidson Institute Working Paper 470}

Visegrad trade to industrial countries has always been the highest, while the shares from the ASIA and BUR groups have been consistently the lowest (indeed almost a third of the Visegrad share throughout). Despite their relatively high initial shares, the adjustment was rapid: these export shares rise from about 55 per cent to more than 70 per cent for Vysegrad group, from 45 to 55 per cent for the Balkan countries, and from roughly 15 to 25 per cent for BUR and Asia economies. Keeping in mind the collapse of the Soviet Union and its implications for interindustry trade, the speed of re-orientation of trade in the Baltics is remarkable. The percentage of Baltic exports to industrial countries grew from less then 5\% in 1991 to more than 50\% in 1998. This compares very favourably with increases in the shares of the ASIA and BUR groups from about $7 \%$ to about $24 \%$ and from about $14 \%$ (1992) to about $26 \%$, respectively, over the same period.

Table 8

Trade Reorientation (Share of Exports to Industrial Countries)

Regional Averages: 1990-1998

\begin{tabular}{lrrrrrrrrr}
\hline & 1990 & 1991 & 1992 & 1993 & 1994 & 1995 & 1996 & 1997 & 1998 \\
& & & & & & & & & \\
BALTIC & 6.25 & 3.70 & 41.73 & 42.97 & 42.52 & 49.52 & 46.56 & 56.82 & 55.42 \\
BALKAN & 43.58 & 47.70 & 32.89 & 38.03 & 40.17 & 40.87 & 44.35 & 47.81 & 54.34 \\
VISEGRAD & 54.13 & 64.07 & 69.46 & 67.08 & 68.47 & 68.78 & 68.10 & 69.68 & 72.96 \\
ASIA & 8.40 & 6.87 & 17.50 & 22.44 & 26.50 & 23.93 & 21.53 & 19.59 & 23.12 \\
BUR & 21.61 & 18.55 & 13.76 & 16.79 & 28.00 & 26.42 & 24.76 & 24.59 & 26.60 \\
& & & & & & & & & \\
CEEB & 34.65 & 38.49 & 48.03 & 49.36 & 50.38 & 53.06 & 53.00 & 58.10 & 60.91 \\
CIS & 15.00 & 12.71 & 15.63 & 19.61 & 27.25 & 25.17 & 23.15 & 22.09 & 24.86 \\
& & & & & & & & &
\end{tabular}

Notes: Authors' calculations using IMF's Direction of Trade Statistics (various issues) data. See text for definition of regional groups.

What dynamics would one expect for openness in transition economies? It was often claimed that central planning created excessively integrated economies and, if this assessment is correct, the collapse of CMEA would lead to somewhat less open economies. A closer look at the evolution of openness brings up two observations. First, there was a relatively turbulent period characterized by a strong decline of the ratio in the case of CIS in 1991, and a sharp rise in openness for both CEEB and CIS in 1992. Second, the trade-to-GDP ratio was relatively 
stable over 1992-1997, although slowly but steadily declining in the case of CIS. In 1997, both CEEB and CIS countries are not less but rather more open economies than at the start of transition. This is clearly so for Balkan, Vysegrad and Baltic countries whose openness (trade to GDP ratio) increased by 40 and 30 per cent respectively. BUR and Asia countries seem to have the same trade-to-GDP ratios as at the beginning of transition. An alternative but often preferred openness measure, trade-to-GDP (PPP) ratio reveals a similar trend: these economies are gradually becoming more open. At a less aggregated level the same tendency has prevailed: the openness of transition economies has increased continuously ${ }^{28}$.

In sum, the performance of foreign trade in transition economies suggests the following developments, which seem to be general enough to qualify for one more stylized fact of transition. There was a common decline and partial recovery pattern in the dynamics of foreign trade. Trade patterns have changed in that the share of industrial economies as destination rose significantly. The collapse of the CMEA was the major reason for the changing trade patterns in the initial stage of transition, while better export performance in western markets vis-à-vis eastern ones seems to dominate later. The data suggest that there has been no tendency for transition economies to become less open, and in 1999 they were relatively more open than under central planning.

\subsection{Structure changed}

Although one definition of the transition process is the structural change consisting in the reallocation of resources on the basis of market incentives, it is useful to analyze the structural change that actually occurred in transition economies and compare it with predictions from the experience of developing countries. This may help to emphasize how much of the structural change reflects a movement toward an economic structure consistent with relative prices.

\footnotetext{
${ }^{28}$ Oleh Havrylyshyn and Hassan Al-Atrash (1998) used a cross-section regression analysis to answer the question of how trade-to-GDP (PPP) ratios of transition economies in 1995 compared to those of "more established market economies." Their conclusion was that (with some puzzling exceptions) transition economies were as open as the "benchmark" economies. One might note, however, that this trade-to-GDP (PPP) has not been stable and mostly moved upwards since 1995 (except for Asia), implying that transition economies became even more open.
} 
According to the Chenery hypothesis (Hollis Chenery, 1960), ${ }^{29}$ as real per capita GDP grows, the structure of output changes in that the share of agriculture declines, while that of services increases. The socialist economy had a structure of output that favoured industry and repressed services, as the latter were considered, in Marxist terminology, "unproductive." One should then expect the structure of output to change rapidly in the first ten years of transition. That is precisely what one finds, but with important caveats both in terms of which sectors adjusted faster and in which group of countries (CEEB or CIS) that happened more prominently.

Not surprisingly, industry was the largest sector at the beginning of the transition. Comparing the shares of value added by industry in GDP between the CEEB and CIS countries, notice that in 1990 it was higher in the former than in the latter (around 47\% and 42\%, respectively), but it declined faster in the CEEB than in the CIS group. In 1998, the share of industry stands at around $32 \%$ of GDP in the CEEB countries (compared to 34\% in the CIS). The declines in the manufacturing shares are very much in line with these changes. Yet one observes the opposite regarding the share of servic es in GDP. These shares are basically identical in 1990 in the CIS and CEEB groups (approximately 35\% of GDP), but they increase in the next six years at different speeds, reaching 55\% of GDP in the CEEB countries in 1996 and 47\% in the CIS countries.

Although the changes in the share of agriculture pale in comparison, they are still interesting, in particular when contrasting the CEEB with the CIS experience. In the CIS countries, the share of agriculture in GDP declined from 27 to 20 percent between 1990 and 1998. The discrepancies between simple averages and GDP per capita-weighted averages can be safely ignored for the CIS but not for the CEEB countries. For the latter, the unweighted average does not seem to change at all in those years and stands at $18 \%$ of GDP. Yet, when examining GDP per capita-weighted averages, this share declines from 15\% of GDP in 1990 to a mere 9\% in 1996. One finds the reason for this discrepancy in the Balkan countries, for which the simple average increases in 1990-1998 while the weighted average decreases, although in both cases the share of agriculture is still twice as high for the remaining (non Balkan) CEEB countries.

\footnotetext{
${ }^{29}$ Moses Syrquin (1988) surveys this large literature and Roland Döhrn and Ullrich Heilemann (1996) present a test of the hypothesis for early transition.
} 
Table 9

Structural Change (Value Added in Industry as Percentage of GDP)

Regional Averages: 1990-1998

\begin{tabular}{lccccccccc}
\hline & 1990 & 1991 & 1992 & 1993 & 1994 & 1995 & 1996 & 1997 & 1998 \\
& & & & & & & & & \\
BALTIC & 48.89 & 44.93 & 37.48 & 36.06 & 32.65 & 32.28 & 31.07 & 31.13 & 29.57 \\
BALKANS & 45.41 & 39.37 & 34.89 & 35.56 & 36.13 & 31.66 & 31.19 & 30.71 & 30.38 \\
VISEGRAD & 47.79 & 46.01 & 39.32 & 37.72 & 35.51 & 36.17 & 35.07 & 35.49 & 35.35 \\
BUR & 46.72 & 48.11 & 46.65 & 39.70 & 42.26 & 39.67 & 38.18 & 37.88 & 38.58 \\
ASIA & 36.36 & 37.40 & 36.30 & 37.04 & 31.93 & 31.87 & 30.56 & 28.30 & 29.93 \\
CEEB & & & & & & & & & \\
CIS & 47.36 & 43.44 & 37.23 & 36.45 & 34.76 & 33.37 & 32.44 & 32.44 & 31.77 \\
& 41.54 & 42.75 & 41.48 & 38.37 & 37.09 & 35.77 & 34.37 & 33.09 & 34.26 \\
\hline
\end{tabular}

Notes: Authors' calculations using 2000 World Development Indicators data. See text for definition of regional groups.

How deep is this process of structural change in international perspective? To answer this question first recall that most of the CIS countries end this period as low income or middle-lower income, while the majority of the CEEB countries in the late 1990s are classified as uppermiddle income economies. The declines in the share of agriculture in GDP between 1990 and 1998 in the CS countries are very much in line with those between 1980 and 1998 for low income or middle-lower income economies. ${ }^{30}$ The same can be said for the behaviour of this share in the CEEB countries vis-à-vis its change between 1980 and 1998 in the upper-middle income economies. Therefore, the sources of dynamism are to be found in the increases in the shares of services and in the declines in the shares of industry.

The rate of decline of the shares of industry in GDP is more than twice as high in the CEEB countries than for the upper-middle income group. A similar statement is true with respect to those shares in CIS countries vis-à-vis the changes observed in low income or middle-lower income countries. Regarding services, note that the rate of increase in the share of services in GDP is more than twice as high in the CEEB countries than for the upper-middle income group.

\footnotetext{
30 World Bank, 1999/2000 World Development Report (Table 12, p. 252-253) provides population weighted averages for these shares in upper-middle, low and middle-lower income countries.
} 
Yet, the rate of increase of the shares of services in GDP in the CIS countries are not noticeably different from this rate of increase in low income or middle- lower income countries. ${ }^{31}$

On this basis, we claim that during the transition the structure changed. The sectoral composition of GDP changed rather fast. In the CEEB countries we observe the share of services in GDP growing rapidly, while the share of industry is similarly shrinking. On the other hand, in the CIS countries structural change take place in a slightly different manner. It is driven by a more modest growth in the share of services, and more modest declines (vis-à-vis those in the CEEB countries) in the shares of agriculture and industry. The process of structural change in the CEEB countries is impressive even when compared to similar changes in countries at the same levels of development. On the other hand, the process of struc tural change in the CIS countries is not impressive in international perspective, as similar changes can be observed in low income and middle-lower income countries.

\subsection{Institutions collapsed}

As the transition experience has accumulated, it has become clearer that the "persistent disparity between progress in liberalization and privatization, on the one hand, and in the development of institutions that support markets and private enterprise (...), on the other" (EBRD, 1999, p. 26) is directly related to overall economic performance. Countries where this disparity decreased during the transition performed better than countries where this disparity was allowed to persist, or even to increase. A major impediment to assess the role of institutions in explaining economic performance during the transition refers to the difficulties in identifying theoretically-sound measures of those institutions that are relevant for growth. This constraint is particularly severe: it demands a systematic panel data set of institutional indicators instead of the incomplete and mostly cross-sectional data available so far. A first and very preliminary attempt to circumvent this problem is offered by Campos (2000). The author uses the concept of "governance," as developed by the World Bank (1994), to put forward a set of four indicators for different institutional dimensions of "governance," for 25 transition countries, during the period 1989 and 1998.

\footnotetext{
${ }^{31}$ See World Bank, 1999/2000 World Development Report (Table 12).
} 
Let us examine the "rule of law" indicator. Notice first that there are two important issues in constructing the indicator. One relates to the aggregation of different underlying components, and the other to the choice of the underlying components. As for the aggregation, a simple procedure was adopted: the series was re-coded over an identical 1 to 10 scale (re-based first if needed) and then aggregated by simple averaging. As for the underlying components, the indicator for "the rule of law" was constructed on the basis of three indicators, the first two focusing on enforcement and the latter on the type and substance of the "law" itself. The first is an ICRG indicator ("rule of law tradition") reflecting the country-specific degree to which citizens are willing to accept the established institutions for making and implementing laws and resolving disputes. Higher scores of "rule of law" indicate that the country has sound political institutions and a strong court system. The second indicator, property rights, is "factor \#8" from Kim Holmes, Bryan Johnson and Melanie Kirkpatrick (1997, 1998). It measures, on a 1-5 scale, the government influence over the judicial system, the commercial code defining contracts, the sanctioning of foreign arbitration of contract disputes, corruption within the judiciary system, delays in judicial decisions, and the extent of legally granted and protected private property. The third indicator upon which this measure is based is "rule of law" from Adrian Karatnycky, Alexander Motyl and Boris Shor (1998) which measures on a 1 to 7 scale whether a postcommunist constitution has been adopted, whether it does provide for property and human rights, whether the criminal code has been subject to reform, whether judges rule fairly and impartially and whether they were appointed during the communist era, whether the courts are free of political control, whether the state provide public defenders, and whether ethnic minority rights are protected. 
Table 10

Government Expenditures as Percentage of GDP

Regional Averages: 1990-1999

\begin{tabular}{|c|c|c|c|c|c|c|c|c|c|c|}
\hline & 1990 & 1991 & 1992 & 1993 & 1994 & 1995 & 1996 & 1997 & 1998 & 1999 \\
\hline BALTIC & 49.10 & 38.70 & 31.53 & 36.87 & 39.57 & 39.90 & 38.03 & 37.63 & 40.50 & 43.00 \\
\hline BALKAN & 55.57 & 42.73 & 45.08 & 39.48 & 39.78 & 38.33 & 37.52 & 36.23 & 36.18 & 37.62 \\
\hline VISEGRAD & 47.63 & 49.10 & 50.40 & 49.00 & 48.02 & 46.30 & 45.62 & 45.82 & 44.30 & 43.90 \\
\hline ASIA & 39.85 & 37.81 & 42.77 & 45.35 & 34.73 & 25.81 & 23.60 & 24.50 & 25.60 & 25.83 \\
\hline BUR & n.a. & n.a. & 58.53 & 51.80 & 47.93 & 38.17 & 42.47 & 44.00 & 41.73 & 40.33 \\
\hline CEEB & 50.77 & 43.51 & 42.34 & 41.78 & 42.46 & 41.51 & 40.39 & 39.90 & 40.33 & 41.51 \\
\hline CIS & n.a. & n.a. & 50.65 & 48.58 & 41.33 & 31.99 & 33.03 & 34.25 & 33.67 & 33.08 \\
\hline
\end{tabular}

Notes: Authors' calculations using 2000 World Development Indicators data. See text for definition of regional groups. n.a. indicates data not available.

Table 10 shows the regional averages for the "rule of law" indicator between 1989 and 1998. It is clear from these data that the process of institutional build-up took off much faster in the Central and Eastern European countries, despite starting at a much higher level. It should be also noted that among the CIS countries, Belarus, Ukraine and Russia are characterized by an extremely slow process of deepening of a rule of law tradition. ${ }^{32}$ There is also considerable heterogeneity among CEEB countries; on the one hand we can see a consistent process of institutional deepening in the Visegrad and Baltic countries, while very little of it is observed in the Balkan group.

Institutional choices are also related to the size of the government, often measured in the literature as the share of government consumption in GDP. The study of the effects of government size on economic growth is highly controversial, to say the least, and consensus is being built upon the notion that different types of expenditures have different effects on

\footnotetext{
$\overline{32}$ To the point that the average for the ASIA countries in 1997 surpassed the BUR average.
} 
economic growth. ${ }^{33}$ Table 11 shows the evolution of government consumption in transition economies between 1990 and 1996. There seems to be no clear trends across those groups with one exception, namely that in the Baltic countries government consumption as a share of GDP is increasing throughout the period. It should also be noted that these levels of government consumption are high in comparative perspective (except for the ASIA countries). In 1998, government consumption in low-income economies averaged 12 percent of GDP, in lowermiddle income countries it averaged 14 percent, in upper-middle income countries 11 percent, and in high-income countries it averaged 17 percent of GDP. ${ }^{34}$

\begin{tabular}{|c|c|c|c|c|c|c|c|c|c|c|}
\hline & & & egiona & $\begin{array}{l}\text { Tabl } \\
\text { Rule o } \\
\text { Avera }\end{array}$ & $\begin{array}{l}11 \\
\text { f law } \\
\text { ses: } 199\end{array}$ & 0-1999 & & & & \\
\hline & 1989 & 1990 & 1991 & 1992 & 1993 & 1994 & 1995 & 1996 & 1997 & 1998 \\
\hline BALKANS & 3.611 & 4.389 & 4.250 & 4.111 & 5.333 & 5.889 & 6.167 & 6.389 & 6.500 & 6.500 \\
\hline VISEGRAD & 6.800 & 7.933 & 8.133 & 8.133 & 8.633 & 8.800 & 9.233 & 9.633 & 9.833 & 9.833 \\
\hline BALTIC & 4.667 & 5.667 & 7.789 & 8.333 & 8.333 & 8.333 & 9.111 & 9.433 & 9.500 & 9.500 \\
\hline BUR & 4.000 & 5.000 & 5.289 & 5.056 & 5.056 & 5.056 & 5.056 & 5.056 & 5.056 & 5.056 \\
\hline ASIA & 2.250 & 2.375 & 2.271 & 2.937 & 3.896 & 3.896 & 4.417 & 4.913 & 5.625 & 5.625 \\
\hline CEEB & 5.026 & 5.996 & 6.724 & 6.859 & 7.433 & 7.674 & 8.170 & 8.485 & 8.611 & 8.611 \\
\hline CIS & 3.125 & 3.688 & 3.780 & 3.997 & 4.476 & 4.476 & 4.736 & 4.984 & 5.340 & 5.340 \\
\hline
\end{tabular}

Note: Author's calculations based on data from Campos (2000). See text for definition of regional groups.

In summary, the transition started off with the implosion of a tight political-economic system. Its collapse entails the fading of an institutional framework that persevered despite all its well-known problems. This generated an institutional vacuum. The data used in this section serves to show the painful, and in many cases slow, effort to build-up institutions that could support a modern market economy.

33 See William Easterly and Sergio Rebelo (1993), Alberto Alesina and Roberto Perotti (1996), Shantayanan Devarajan, Vinaya Swaroop and Heng-fu Zou (1996), Stephen Miller and Frank Russek (1997), John Baffes and Anwar Shah (1998), and references therein. Analyses focusing on transition economies include Ke-young Chu and Gerd Schwartz (1994), Kornai (1995), Coricelli (1997) and Marek Dabrowski (1997).

${ }^{34}$ Source is World Bank, 1997 World Development Report, Table 13, pp. 238-239. 


\section{William Davidson Institute Working Paper 470}

\subsection{Transition costs}

The objective of this sub-section is to briefly discuss the extent to which output performance in transition has been associated with other measures of well-being such as poverty and inequality, longevity and morbidity, and literacy. One of the stylized facts of the transition so far is that the output fall has been associated with substantial costs in terms of rapidly rising poverty and inequality, as well as the sharp deterioration of various social indicators (notably, life expectancy and enrollment rates). ${ }^{35}$ Three important issues to keep in mind are: first, that the starting (i.e., 1989) levels were high vis-à-vis countries at similar levels of development. One of the most trumpeted successes of the pre-1989 regimes was the delivery of health, education and income equality. Second, that the drastic fall in output was not accompanied by equally drastic falls in consumption levels. In other words, consumption fell less than output, so that the welfare costs of the early years of the transition were smaller than those associated with the slowdown in economic activity. Third, here, the divide between Central and Eastern European and Former Soviet Union countries is seen very clearly. For instance, mortality rates rose faster and were higher throughout in the latter group of countries (Brainerd, 2001).

Arguably the first dimension over which this heavy social burden was identified regarded the rapid changes in mortality rates, prompting the World Bank's 1996 World Development Report to raise the question "Is transition a killer?" The early years of the transition witnessed a rapid increase in mortality rates, and a major explanatory factor for these is the increase in adult male mortality rates. The effect of transition seems to be straightforward. The rising mortality rate of adult males is explained in large part by the psychological stress associated with turbulent times, with rising unemployment, poverty, and alcohol consumption (Elizabeth Brainerd, Ichiro Kawachi and Bruce Kennedy, 1998). Further, the much smaller increases in adult male mortality rates observed in the Caucasus and Central Asian economies (vis-à-vis all other former Soviet Union countries) seems closely related to the preponderance of family and other informal arrangement in cushioning those effects of the transition ("social capital"). Note that increases similar to the ones in the Caucasus and Central Asia did not occur outside of the former Soviet Union countries. Among transition economies, public health expenditures (as percent of GDP)

\footnotetext{
${ }^{35}$ See Elizabeth Brainerd (1998), Judith Shapiro (1995), John Flemming and John Micklewright (1999), EBRD Transition Report (1999), UNDP (1998), and UNICEF (1999).
} 
show an increasing trend until $1994,{ }^{36}$ when they started to decline, returning to their 1990 level (the exception is the Asia group, where health expenditures decrease from the start). However, the increase in health expenditures did not hamper the overall decline of life expectancy at birth until 1993. As expected, the largest decline was for the FSU countries not for the CEEB.

Table 12

Life Expectancy at Birth for Males (in years)

Regional Averages: 1990-1999

\begin{tabular}{lcccccccccc}
\hline & 1990 & 1991 & 1992 & 1993 & 1994 & 1995 & 1996 & 1997 & 1998 & 1999 \\
& & & & & & & & & & \\
BALTIC & 65.13 & 64.50 & 63.90 & 62.43 & 61.53 & 62.03 & 64.26 & 64.86 & 65.00 & n.a. \\
BALKANS & 67.89 & 67.81 & 67.33 & 66.57 & 66.90 & 66.79 & 67.06 & 67.12 & 67.30 & 67.19 \\
VISEGRAD & 67.04 & 67.12 & 67.38 & 67.80 & 67.94 & 68.31 & 68.84 & 69.06 & 69.09 & 70.84 \\
ASIA & 65.99 & 65.50 & 65.70 & 62.86 & 63.78 & 64.14 & 64.40 & 65.22 & 65.53 & n.a. \\
BUR & 65.23 & 64.33 & 63.63 & 61.90 & 61.20 & 60.99 & 61.54 & 61.90 & 61.97 & n.a. \\
CEEB & 66.69 & 66.48 & 66.20 & 65.60 & 65.46 & 65.71 & 66.72 & 67.01 & 67.13 & 69.02 \\
CIS & 65.61 & 64.92 & 64.67 & 62.38 & 62.49 & 62.57 & 62.97 & 63.56 & 63.75 & n.a. \\
& & & & & & & & & & \\
\hline
\end{tabular}

Notes: Authors' calculations using 2000 World Development Indicators data. See text for definition of regional groups. n.a. indicates data not available.

Similar developments are observed with regard to changes in education indicators. For instance, the literacy rate declined in all the countries for which data are available. ${ }^{37} \mathrm{We}$ commented above on the changes on secondary school enrollment rates, similar developments can be seen with respect to primary school enrollment. The CEEB-FSU differences in this case is reinforced by the fact that enrolment declined faster in the least urbanized countries, which happened to be FSU countries. Interestingly, there seem to be no common pattern regarding public spending on education.

As for poverty and inequality, the emerging consensus is that they have both increased sharply in the beginning of the transition and have, so far, not shown signs of declining. For example, the poverty headcount index (percentage of the population whose income is below the

\footnotetext{
${ }^{36}$ The same trend is seen for the division into CEEB and FSU groups, with FSU starting the decline from 1993. As expected, total number of hospital beds and physicians per capita were also declining in these first ten years.

${ }^{37}$ The data cover only 12 countries for the years 1990, 1995 and 1997. See UNICEF (1999).
} 
poverty line) was around 4 percent in the late 1980s increasing to $45 \%$ in 1993-95 (Branko Milanovic, 1998, esp. Table 5.1). Income inequality, as measured by the Gini coefficient, has also increased. Because of transition itself (price liberalization and privatization fuelling higher wages in the private sector), one could argue that is normal for inequality to increase. Yet, it is important to note that inequality increased faster and more decisively among former Soviet Union countries.

In sum, the relationship between economic growth and various measures of well-being during the transition is marked by the rapid appearance of substantial social costs. Although inequality was expected to rise, there were few reasons to expect health and education conditions to deteriorate the way they did.

\subsection{The Magnificent Seven: Summary of the Stylised Facts of the Transition}

Table 13 summarizes what we consider to be the seven main stylized facts of the transition so far. Based on our previous analysis we believe that the following should stand as a robust set even in the face of (needed) future revisions and refinements in the underlying data. We think that there is enough evidence to argue that, in this first ten years, output fell, labor moved, the stock of physical capital shrank, there was a rapid and intense re-orientation of international trade towards the West, the structure of the economy changed, there was rapid collapse of institutional structures followed by a vacuum in many countries, and the transition involved large social costs principally in terms of worsening income inequality, mortality and poverty rates. The next section presents an overview of the theoretical and empirical literature in the light of this set of stylized facts. 
Table 13.

The Magnificent Seven:

Stylized Facts of Ten Years of Transition

Stylized fact

(1) Output Fell

(2) Capital Shrank

(3) Labor Moved

(4) Trade Reoriented

(5) The Structure Changed

(6) Institutions Collapsed

(7) Transition Costs

\section{Comments}

Output fell in all countries of the former eastern Bloc, in stark contrast with development in China and Vietnam (where growth has been fast and sustained). The exact magnitude of the fall is a matter of controversy, inter alia, because of the sizeable informal sectors that quickly emerged.

Capital stocks reduced dramatically during the transition, although the expectation is that efficiency has increased.

Labor moved in all senses, but the most obvious one: measures of geographical mobility are very low. Yet, we observe large changes in labour markets status, sectors, and occupations.

CMEA trade collapsed and was re-directed to industrial countries in a very short period of time, with few exceptions (the slow re-orientation in BUR is led by Ukraine and Belarus, not Russia).

The share of value added by industry in GDP declined rapidly. In the CEEB case, this is due almost exclusively to the increase of the services share. In the case of CIS, the reasons for the slower decline are much less clear-cut.

The fall of communism created an enormous institutional vacuum. Although efforts to understand and measure it are just starting now, its effects are sizeable and omnipresent.

One of the surprises of the transition was the appearance of unexpected costs. The rise of unemployment and income inequality was expected. The rise in mortality rates and the decline in school enrolment rates were not expected. 
Before proceeding, we should comment on the important issue of economic reform in the transition process. As we mentioned earlier, the debate in this literature is whether initial conditions or economic reform policies have played the crucial role during the transition process so far. One problem in gauging the role of policies is the difficulty in obtaining reliable measures. The available ones are not detailed enough and more often than not are based on Western experts' judgement, when they need not be. ${ }^{38}$ With these caveats in mind, Table 14 shows a measure of economic reform that is widely used in this literature, namely De Melo, Cevdet, Gelb and Tenev (1997) "cumulative liberalization index". Higher values indicate a more intense, deeper and wider reform effort. The data show that reform has progressed much faster in Central and Eastern European than in the former Soviet Union countries. It is surprising to learn that we can not distinguish the ASIA from the BUR countries. Also of interest is that the reform effort in the BALKAN countries has been much more modest than in the Visegrad countries as well as in the Baltic economies. Despite these interesting insights, we believe better data is needed before attempting further analysis.

Table 14

Cumulative index of internal economic liberalization, Regional Averages: 1989-1998.

\begin{tabular}{lcccccccccc}
\hline & 1989 & 1990 & 1991 & 1992 & 1993 & 1994 & 1995 & 1996 & 1997 & 1998 \\
& & & & & & & & & & \\
BALKANS & 0.28 & 0.54 & 0.97 & 1.57 & 2.24 & 2.93 & 3.66 & 4.38 & 5.14 & 5.91 \\
VISEGRAD & 0.42 & 0.85 & 1.60 & 2.42 & 3.26 & 4.12 & 5.01 & 5.90 & 6.80 & 7.71 \\
BALTICS & 0.05 & 0.20 & 0.52 & 1.08 & 1.84 & 2.70 & 3.57 & 4.46 & 5.36 & 6.26 \\
BUR & 0.04 & 0.08 & 0.18 & 0.49 & 0.84 & 1.26 & 1.82 & 2.40 & 2.95 & 3.49 \\
ASIA & 0.04 & 0.08 & 0.17 & 0.45 & 0.80 & 1.20 & 1.71 & 2.27 & 2.86 & 3.46 \\
& & & & & & & & & & \\
CEEB & 0.25 & 0.53 & 1.03 & 1.69 & 2.45 & 3.25 & 4.08 & 4.91 & 5.77 & 6.62 \\
CIS & 0.04 & 0.08 & 0.18 & 0.47 & 0.82 & 1.23 & 1.76 & 2.33 & 2.91 & 3.48 \\
\hline
\end{tabular}

Notes: Authors' calculations using De Melo et al (DDGT, 1997) indexes. See text for definition of regional groups.

The above seven facts apply to the countries of Central and Eastern Europe and the former Soviet Union and thus should not be seen as stylized facts of transition in general.

$\overline{38}$ The point here is that for, say, "rule of law," an expert's judgment is necessary, while for, say, "number of key prices liberalized in a certain year" we can clearly have a measure that is not necessarily based on expert's judgment but on hard evidence. 


\section{William Davidson Institute Working Paper 470}

Indeed, the experience in Asia has been very different and a review of developments in transition economies cannot afford to exclude some of the fastest-growing countries. Economic performance in China and Vietnam during the 1990s is impressive and markedly contrasts with the performance of the European transition economies discussed above. ${ }^{39}$

A large body of research addresses these differences. Why have these Asian economies been so successful in conducting transition and the former Soviet bloc economies so unsuccessful? Initial conditions certainly play a role, not only because they provide for major differences between the two groups of countries. China, and the Asian economies in transition in general, did not embark in political and economic transitions simultaneously, have a relatively large share of agriculture in employment and in GDP, have much lower per capita incomes, and were relatively less integrated with CMEA. Institutions also account for an important difference: Yingyi Qian, Gérard Roland and Chenggang Xu (1999) argue that because the Soviet-type economy was organized in specialized ministries while the Chinese-Type economy was organized on a regional basis, more latitude was allowed for experimentation and thus for gradualism. Chinese reform started with decentralisation in 1979 (Qian and Roland, 1998). Local governments were given significant autonomy and that has allowed needed experimentation with a number of reforms as well as the rapid entry of new firms (the TVEs, township and village enterprises, being a prime example). The new entrants generated an interesting paradox in that considerable competition emerged without privatisation and property rights well defined by law (McMillan, 1997). Using the space for experimentation meant that successful reforms were gradually introduced (on a national scale). Lawrence Lau, Qian and Roland (2000) discuss the advantages of the dual-track approach to price liberalisation. They note that liberalisation in China involved the government slowly phasing out planned prices and quantities. Balancing the plan and market-tracks did this, as agents could buy and sell at markets prices only once plan obligations were fulfilled. This process culminated with most prices being liberalised by the mid1990s (Qian, 2000). ${ }^{40}$ The adoption of a reform strategy marked by gradualism and sequencing

\footnotetext{
${ }^{39}$ The performance of Mongolia is similar to that of the CIS countries. Like a former Soviet Union economy, it experienced a severe fall in output. Yet it had an earlier and sustained recovery. Growth rates are still modest compared to Laos, Vietnam and China (Sanjay Kalra and Torsten Slok, 1999). Average growth rates in Laos are higher than in Mongolia but significantly lower than in Vietnam. On China, see John McMillan and Barry Naughton (1992), Gregory Chow (1993), Naughton (1995), Loren Brandt and Xiaodong Zhu (2000) and Yingyi Qian (2000). For a revisionist perspective, see Alwyn Young (2000). On Vietnam, see Christina Dawkins and John Whalley (1996), James Riedel and Bruce Comer (1997) and Naughton (1996).

${ }^{40}$ The reform process in Vietnam is similarly characterized as gradualism, as opposed to the reform in
} 
concerns seems to be intrinsically linked to the much superior performance of China and Vietnam vis-à-vis the other transition economies.

\section{Growth in Transition: The Theoretical Literature}

The theoretical literature on transition can usefully be divided in two groups, one focusing on the initial fall in output, the other on medium term issues. The short time span that covers the experience of transition from a planned to a market economy makes it impossible for the analysis of economic growth to neglect the initial sharp, and largely unexpected, fall in output. Moreover, in some instances the initial collapse translated into a persistent depression. Following the collapse of output, a lively debate started on its causes. Several observers claimed that such a collapse could be simply explained as a Keynesian recession, driven by a fall in consumer demand (Blanchard, Rudiger Dornbusch, Paul Krugman, Richard Layard and Lawrence Summers, 1991, Andrew Berg and Jeffrey Sachs, 1992, David Lipton and Jeffrey Sachs, 1990, Roman Frydman, Stanislaw Wellisz and Grzegorz Kolodko, 1991, among others). Other observers argued that the fall in output could not be described as a simple Keynesian recession, as the timing and the magnitude of the collapse suggested a different interpretation, based on the concept of "trade implosion". ${ }^{41}$ The phenomenon of "trade implosion" can be ascribed to the break-up of the old system of coordination of production and exchange, substituted with a system of decentralized decisions and free market. The absence of fundamental market institutions implied that the old mechanisms of production and trade could not be quickly replaced by new well-functioning mechanisms. Kornai (1994), for instance, defined the output fall as a "transformational" recession, related to the overall transformation of the economic system. This view appears relevant for a longer run perspective, as it pointed out the risks of a prolonged period of recession, or low-output equilibrium. The "trade implosion" approach stresses the importance of institutional factors in affecting output performance in economies in transition. Such institutional factors, as for instance institutions relating to financial markets, play a fundamental role in the growth literature as well.

\subsection{Explaining the Initial output collapse}

Laos and Mongolia.

${ }^{41}$ The term was first used in connection with the output collapse in economies in transition by Calvo and Coricelli (1993). 
The sharp and unexpected fall in output is a puzzle for economic theory. First, liberalization of prices, dismantling of trade barriers and elimination of pervasive state intervention in economic activity, should have brought large efficiency gains. Second, based on the experience of programs implemented in developing market economies, stabilization per se should not have caused a sharp fall in output. For instance, in Latin America and Israel stabilization programs relying on the exchange rate as an anchor to reduce inflation were not associated with significant output decline, at least in the initial phase of the programs (Miguel Kiguel and Nissan Liviatan,1989; Calvo and Vegh, 1993). Moreover, in market economies, the output performance of stabilization programs relying on the exchange rate as an anchor differed sharply from that of countries that used monetary aggregates as an anchor. By contrast, in transition economies output fell irrespective of the type of stabilization program implemented. Therefore, the experience of transition economies cannot be easily explained with existing models used to analyze market economies. In particular, for transition economies, supply-side explanations are likely to be more relevant than simple Keynesian models.

Within the literature on the initial output collapse, two main contributions stand out. One underlines the role of credit markets, the other the role of the so-called disorganization.

\subsection{Credit market imperfections}

In a planned economy, the artificial structure of production and trade imposed by the planning system made irrelevant credit markets, and to some extent money, at least in connection to the enterprise sector. Dismantling of the planning system implied that production and trade were not only decentralized but they were carried out through monetary or credit arrangements. Development of credit markets requires time. The availability of cash for transactions by enterprises was constrained by official credit, given that firms lacked financial savings that were illegal in most centrally planned economies (Garvy, 1972). Calvo and Coricelli (1992, 1993) single out the credit market as one of the fundamental institutions missing in the former centrally planned economies. The collapse of CMEA trade can also be seen as an example of trade implosion, related to the abandonment of an old mechanism of trade and netting out of payments, without the substitution with a private credit market.

The imposition of tight financial policies at the time of price liberalization likely determined a situation of credit crunch for enterprises. The contraction of central bank credit 


\section{William Davidson Institute Working Paper 470}

resulted in a contraction in overall credit to the economy, as private credit markets could not develop overnight.

Liquidity shortage can in principle explain a temporary fall in output. Over time, firms can accumulate monetary balances and converge to the optimal level of output that would have been reached in the presence of perfect credit markets. Accordingly, the implied behavior of output would follow a U-shaped pattern. An implication of this view is that output decline should be accompanied by a decline in productivity. Moreover, real wages would drop as well, as enterprises attempt to generate liquidity to purchase inputs.

The "credit crunch" approach has been extended to account for the possibility of longer term stagnation, a phenomenon observed in several transition countries, especially in the FSU. These extensions (Calvo and Coricelli, 1996; Dalia Marin and Monika Schnitzer, 1999; Clifford Gaddy and Barry Ickes, 1998) have shown how the initial credit crunch could lead to a "bad equilibrium", with persistent low output. The main channels of these bad equilibria are the explosion of inter-enterprise arrears and barter trade. Generalized non payments and the widespread use of barter trade, while cautioning the effect of credit crunch at the enterprise level, may lead to inefficient macroeconomic equilibria. Both inter-enterprise arrears and barter are at the same time symptoms and causes of extremely high credit risk. Barter trade eliminates credit risk by requiring exchange of goods as form of payment. Inter-enterprise arrears reflect default in payments in transactions among enterprises. Widespread use of these forms of payment technologies implies large costs in terms of loss in output and significant dynamic costs. Indeed, entry of new firms is undermined by the presence of generalized default in payments and/or requirement of barter trade. These phenomena can be thought as forms of dysfunctional institutions, reflecting an endemic lack of trust. Lack of trust is likely to have large negative effects not only on the level of output, but also on growth rates (Alesina and Eliana La Ferrara, 2000). Trust is an important element for the development of a new economic structure based on new networks of enterprises (John McMillan, Simon Johnson, Daniel Kaufmann and Christopher Woodruff, 2000). In a context in which trust is extremely low, existing industrial structures and systems of exchange tend to be perpetuated. Given that in transition economies the initial industrial structure was highly inefficient, the difficulty in building new institutions constitutes an important obstacle for growth. Understanding the phenomenon of generalized inter-enterprise arrears and their implications for output performance requires studying the interaction between macroeconomic and institutional variables, a topic discussed in the literature reviewed below. 
Similar macroeconomic policies applied to countries with different levels of institutional development may lead to sharply different outcomes. The prediction of this approach is that countries starting reforms from a system closer to a rigid central plan were worse off than countries that had partly liberalized their economies, though in an incomplete and inefficient way. Despite their limitations, partial reforms may have contributed to building institutions fundamental for the functioning of a market economy, mainly in the area of financial markets. An indication of this is that inter-enterprise arrears and barter trade did not affect significantly more advanced countries of Central and Eastern Europe, while they proved to be a major obstacle for market reforms in the countries of the former Soviet Union. For instance, in Hungary and Poland private credit markets in the form of trade credit developed soon after the start of reform programs (Calvo and Coricelli, 1996).

\subsection{Disorganization}

An alternative channel which shares some of the main elements of the above view is the socalled phenomenon of disorganization (Blanchard and Kremer, 1997, BK from now on). BK claim that disorganization was an important reason for output collapse especially in countries of the FSU. Disorganization is defined as the break down of economic relations of the old regime, relations that cannot be replaced overnight by new ones. The main concept underlying this view is "specificity" in economic relations between firms. The period of central planning was one of extreme specificity, as firms were locked in relationships with a small number of firms, in many cases only one firm. Firms did not need to accumulate any information on other firms and in particular had no information on the ability and willingness to pay of their customers. A high degree of specificity implies the presence of monopoly rents. Production chains link firms to several suppliers, depending on the degree of complexity of production. Higher complexity implies a larger number of inputs. Under a decentralized system prices are set through a bargaining process. Customer firms, generally state enterprises at the start of reforms, make an offer price to their suppliers. If such a price is below the reservation price of the supplier (eg the outside option for the supplier), the latter does not provide inputs to the state firm and thus output falls. Assuming strong complementarities in production, even the lack of one input implies the impossibility to produce. The reason for inefficient bargaining is that the reservation price is private information of the supplier. An implication of he model is that the larger is the number of 


\section{William Davidson Institute Working Paper 470}

inputs, thus the higher is the degree of complexity of production, the larger will be the output fall. One could thus expect that the output fall would be more pronounced in highly industrialized economies. This may be a reason for the different performance in output of highly industrialized countries of the former Soviet Union with respect to mostly agrarian economies such as that of China (Roland, 2000). Another implication would be that output decline would be worse in countries that started reforms from a more rigid system of central planning. In countries in which firms had already experienced decentralized mechanisms of bargaining, output decisions and even price setting, the adverse effects of inefficient bargaining would be less acute.

A model of disorganization based on search frictions and investment specificity rather than inefficient bargaining is the one by Gérard Roland and Thierry Verdier (1997). In their model, production occurs through a matching process between firms. Efficient production is described as the occurrence of good matches, or matches between good firms. The exploitation of new good matches between customers and suppliers cannot occur instantaneously after liberalization. Search externalities and relation-specific investments produce a temporary output fall after liberalization. Relations existing during the previous regime break down, while new one emerge only gradually over time. Liberalization sets in new good opportunities. This triggers firms to search for good matches. However, there is a search externality, as the higher the number of firms searching is, the lower is the probability of finding a good match, as there are many bad firms searching as well. Investment is relation specific, and it is carried out only when firms find good matches that tie firms over the log run. Therefore, during the search period investment contracts. Despite important differences in the models, Blanchard-Kremer and Roland-Verdier offer a similar explanation for the observed output collapse. The implications of their models are also similar. Liberalization may produce a collapse in output if the necessary conditions for effectively replacing the old relations among firms are not in place. According to Roland (2000) a dual track liberalization approach, like the one followed in China, would solve the problem, by maintaining, for state firms, the old channels and relations. This would make production feasible, and at the same time allowing at the margin entry of new firms that will search for new opportunities.

The disorganization view offers an interpretation of output collapse that is different but not in contrast with the credit crunch view. Indeed, those views may be complementary. ${ }^{42}$

${ }^{42}$ Ronald McKinnon (1991) argues that liberalization and instantaneous dismantling of the old economic 
An explicit attempt to merge the views of Calvo-Coricelli and Blanchard-Kremer has been carried out by Marin and Schnitzer (2000), who conclude that credit constraints may reduce the negative impact of disorganization. This conclusion is not fully convincing. As noted by Blanchard and Kremer the coordination problem in the enterprise sector is made worse by the lack of liquidity. The more complex is the production process, the more important is credit. Although it is conceivable that at the microeconomic level of bilateral bargaining between supplier and customer liquidity constraints may reduce the effects of disorganization by increasing the bargaining power of the customer, at an aggregate level the lack of credit is likely to produce large negative effects on output.

As transition progressed and several countries of Central and Eastern Europe started to grow out of the initial collapse, a literature focusing on medium term perspective and on dynamic issues developed. Structural change and the reallocation of resources across sectors and firms are at the core of this literature.

\subsection{Creative destruction and optimal speed of transition}

A popular view of transition describes output dynamics along a path determined by the sector reallocation of resources. As resources move out of the old state firms into the private sector, productivity increases. If there are adjustment costs, or other imperfections such as search costs, aggregate output is likely to drop initially and increase afterwards, when the private sector has reached a sufficient size. Accordingly, output follows a U-shaped path. The initial contraction in output is reminiscent of a phenomenon of Schumpeterian "creative destruction". Inefficient firms weed out, leaving room for the expansion of new, more efficient firms. A clear signal of such Schumpeterian process would be the increase in productivity accompanying the initial decline in output (in stark contrast with the implications of models in section 3.2 and 3.3. above). Empirical evidence presented in Simon Commander and Fabrizio Coricelli (1995) emphasizes that in the

system would lead to output collapse due to a financial crisis. In the old regime of central planning the tax system relied on state enterprise taxation, while the banking system acted simply as a central clearing house. Decentralization and liberalization implies that the state gives away control on its tax base and, simultaneously commercial banks face the problem of providing credit in a context in which they lack the information and the expertise to act efficiently. Past information on enterprises is irrelevant as the arbitrary system of taxes and transfers made profitability as a bad indicator of efficiency of firms. As a result, liberalization would imply a fiscal crisis accompanied by a crisis of a banking sector that would be exposed to large amounts of bad loans. The conclusions of McKinnon's analysis are similar to those of Roland, and a gradual approach to reform is favored. 


\section{William Davidson Institute Working Paper 470}

initial phase there was little dynamics in terms of job flows, thus indicating that Schumpeterian forces were slow to operate. At first sight, it would appear optimal to make the process of transition as fast as possible, by shortening the initial period of decline in output. However, if one takes into account possible adverse feedbacks, such as fiscal costs of the initial fall in output, or congestion effects in the labor market due to high unemployment, the normative implications of the models are less obvious. For these reasons a literature on the optimal speed of transition emerged.

Perhaps, the most influential work in this area is Phillippe Aghion and Olivier Blanchard (1994). They develop a two sector search model, in which workers displaced from old state firms search for jobs in the new private sector. Job creation in the private sector is a function of profits, current and expected, which in turn depend on wages. The endogenous mechanism of job creation works through an efficiency wage model, in which the rate of unemployment, by reducing wages, stimulates the creation of jobs in the private sector. The shrinking of the state sector is considered a policy variable. Without macroeconomic feedbacks, the best policy would naturally be to shrink the state sector as fast as possible. However, job creation in the private sector depends on net profits, hence on tax rates paid by private firms. Given that the state pays for unemployment benefits out of its budget, the higher is unemployment, the higher would be the tax rate for private firms, not only because the needed public expenditure would be higher, but also because the tax revenue collected from state firms would be lower as the state sector shrinks. This adverse fiscal effect counteracts the potential positive effect of unemployment on job creation in the private sector. As a result, there is the risk that a too fast speed of transition, namely a too fast shrinking of the state sector, derails the transition process, leading to an equilibrium with persistent high unemployment. By dosing the contraction of the state sector the economy could achieve a successful shift of resources to the private sector, that ultimately will absorb all workers in the economy. Although relevant for a normative analysis of the speed of transition and for the role of unemployment, the model is less suited for an analysis of the growth process in transition economies. Indeed, the model implies a constant difference between productivity in state and private firms and, more important, it does not consider the role of investment, both in physical and human capital. In addition, the assumption of an exogenous decline of state firms appears a too strong assumption, that rules out the important interaction between the increase of new private firms and the endogenous shrinking of the state sector.

We now turn to models that tackle directly dynamic issues and the investment process. 


\subsection{Output dynamics and capital accumulation}

One of the main challenges of transition is the replacement of the old capital stock with a new one. The process of over-investment during central planning has left transition countries with an inherited stock of capital largely useless under condition of a market economy and international competition. Even human capital, often cited as a major strength of formerly centrally planned economy appears in many instances inadequate for a market economy. Thus, new investments in physical and human capital represent the main engine of growth in transition economies.

Michael Castanheira and Gérard Roland (2000) develop a Ramsey-type model of optimal growth with two sectors, state and private and Leontieff type technologies. In the private sector firms are equally productive, while in the state sector firms are ordered by decreasing productivity. Moreover, even the most productive state-owned firm is less productive than a private firm. In contrast with other models of transition, in particular Aghion and Blanchard (1994), there are no frictions in the labor market. A consequence of the assumed technology is that return to capital is always higher in the private sector. As a result, all investment takes place in private firms, and the reallocation of labor across sectors is driven by capital accumulation in the new private sector. In turn, investment is determined by optimal savings, which summarizes the speed of transition, defined as the speed of reallocation of labor from state to private firms. The higher return to capital in private firms can be captured only after capital has been installed. With Leontieff technology, hbor does not jump instantaneously from state to private firms, and thus transition is a gradual process. The state sector continuously shrinks. The optimal transition path, defined in terms of the length of transition, depends on the parameters of utility function, on the discount rate, on the technology in state firms and on the capital labor ratio. Along the optimal path growth rates decline as the productivity gains from a shift of resources from state to private firms narrow. It is indeed optimal to close the less productive state firms first. An implication of the optimal path is that growth rates decline over time during transition, but output grows continuously. Therefore, the optimal path is inconsistent with the observed initial fall in output.

Having determined the optimal path, hence the optimal speed of transition, one can analyze the effects of deviations from such a path. In particular, one can analyze the effects of going too fast, by closing state firms at a rate that is initially faster than the one obtained along the optimal path, or of going too slow. It turns out that going slower has no effect on the speed of transition, as the private sector pulls out workers from state firms irrespective of the attempt of 


\section{William Davidson Institute Working Paper 470}

the government to initially close firms below the optimal rate. By contrast, a too fast rate of closing affects the speed of transition, growth and welfare. Interestingly, a faster rate of closure of the state sector may lengthen the transition process and it reduces welfare. This is due to an income effect associated with the decline in output of state firms. From a descriptive point of view it should be noted that the growth rate increases at initial stages of transition with a faster closure of state firms. Thus, the empirical implication of the model for the analysis of growth is that countries that followed a bolder approach to closure of state enterprises should display faster rates of growth initially.

The model by C-R has the advantage of using a framework as close as possible to the standard Ramsey model of optimal growth. However, neglect of important deviations from the general equilibrium model with perfect markets may reduce the empirical relevance of the model. For instance, the assumption that the new private sector pulls out workers from the state sector starting from the less efficient firms may hide the possible important migration out of the state sector of the most productive workers. This migration is likely to reduce the overall productivity of firms in the state sector, a phenomenon that could be captured in models with efficiency wages and heterogeneous labor force. Similarly, with credit market imperfections a squeeze on state firms is likely to penalize all firms, irrespective of their level of productive efficiency, a point made in the literature reviewed in the preceding section. In sum, while very valuable as a framework to discuss the optimal speed of transition, the model does not capture the U-shaped path of output that characterized the transition process.

Models that attempt to combine the mechanisms highlighted by A-B and the investment process analyzed by $\mathrm{C}-\mathrm{R}$ have been developed by Bankhim Chadha and Fabrizio Coricelli (1995). Chadha and Coricelli (C-C from now on) develop a two-sector model that incorporates dynamics of physical capital. The model shares with Aghion and Blanchard the basic structure of the labor market. However, it assumes flexibility in labor markets and imperfections in credit markets. The underlying assumption is that financial sector imperfections should be a more relevant constraint on growth in transition economies than labor market imperfections. In C-C investment in the private sector is subject to adjustment costs. The main analytical contribution of this paper is that investment becomes a function of the rate of unemployment, a function which is highly nonlinear (a similar channel works in Ricardo Caballero and Mohamad Hammour, 1996). It turns out that there is a minimal rate of unemployment required to push the economy towards a successful transition path, a path along which labor shifts continuously from 


\section{William Davidson Institute Working Paper 470}

the state to the private sector. In the model, the contraction of the state sector is endogenous and is determined by the growth of the private sector. Thus, one could speak of a process of "creative destruction". The government can affect such a process by tightening the constraints on state firms, namely by reducing subsidies. ${ }^{43}$ However, a successful transition may require a sufficiently developed safety net for the une mployed. Both the ability to tighten constraints and impose discipline on state firms and the presence of a safety net depend on institutional development, in terms of an efficient judicial system and administration. The model predicts that growth rates should be positively associated with unemployment, up to a critical point after which the expansion of the private sector is capable of absorbing workers leaving the state sector. Another prediction is that, other things equal, countries with poor safety ne ts and poor systems for enforcing discipline in the enterprise sector would show poor growth performance.

Chadha, Coricelli and Kornelia Krajnyak (1993) examine the issue of productivity growth during transition and its connection with the dynamics of the state and private sectors. It is assumed that private firms offer greater scope for productivity growth, associated with accumulation of skills. As in Robert Lucas (1988), the accumulation of skills in the private sector depends on the number of workers employed in the private sector. This endogenous mechanism opens the possibility for multiple equilibrium path. If employment in the private sector does not reach a critical value, transition may derail, with the economy stuck at a low output equilibrium dominated by state firms. As in Chadha and Coricelli (1996), unemployment exerts a positive effect on job creation in the private sector and consequently on the process of productivity growth lead by accumulation of human capital.

The models by Chadha, Coric elli and Krajnyak (1993) and Chadha and Coricelli (1995, 1997) share some of the main conclusions reached by A-B and C-R. Their focus is more on the descriptive than on the normative aspects of transition, and some of their conclusions may serve as a useful reference point for empirical analysis. First, to understand aggregate dynamics is crucial to analyze the asymmetric dynamics of state and private firms. Second, capital market imperfections are likely to be a major impediment to growth. Third, total factor productivity would play a key role as a determinant of aggregate growth only at later stages of transition. Indeed, productivity gains in the new private sector need time to be captured, as they result from the process of accumulation of human capital. Thus, transition is a lengthy and costly process.

43 Chadha and Coricelli (1997) also discuss this point. The concept of subsidies in transition economies should be interpreted in a broad sense, including for instance interest rate subsidies, tax exemptions and tax arrears. 
Several macroeconomic indicators are bound to worsen along a successful transition path. If countries face stringent macroeconomic constraints, on the fiscal and external side, they may be induced to slow down transition, with significant medium term output losses. Incentives to move out of state firms are important. Adequate social safety nets permit workers to abandon outdated state firms. In this area, the experience of CentralEastern European countries has been sharply different from that of the former Soviet Union (Boeri, 2000). The presence of safety nets in CEEs allowed a significant contraction of employment in state firms, whereas in the former Soviet Union workers remained attached for several years after reforms to state firms because of the lack of any outside option in the form of unemployment benefits.

In addition to the availability of fiscal resources during transition, factors improving the functioning of financial markets and institutions favoring the development of new private firms should prove fundamental factors determining the growth performance of transition economies. ${ }^{44}$

An important implication of the two brands of literature reviewed in sections 3.2, 3.3 and 3.4 , is that price liberalization and tight macroeconomic policies do not necessarily foster growth. Institutions enabling the functioning of a market economy are a fundamental precondition for growth. Particularly important are institutions that relate to financial markets. Equally important are institutions such as adequate social safety net.

\subsection{Institutions and growth}

In recent years, the literature on growth has paid increasing attention to the role of institutions in affecting growth rates (Daron Acemoglu, Simon Johnson and James Robinson, 2001, Dani Rodrik, 2000, David Romer, 2000). Transition economies are a unique laboratory for these views. Indeed, central planning was an institutional arrangement that has proven highly inefficient, as shown by the dynamics of total factor productivity (Tables 1 and 2). Mathias Dewatripont and Gérard Roland (1997) effectively define transition as a large scale institutional change.

\footnotetext{
${ }^{44}$ Calvo and Jacob Frenkel (1991) introduce credit market imperfections in a growth model. Lack of information on enterprise creditworthiness, untested in the previous regime creates a situation in which profitable investments are not undertaken. Inefficient financial markets produce a shortening of the horizon of firms, with negative effects on long term growth.
} 


\section{William Davidson Institute Working Paper 470}

The notion of institutions is too vague to lead to a simple theoretical treatment. ${ }^{45}$ Although the theories are still sketchy, several channels have been identified, all of them contributing to what is called social infrastructure, or social capital. Romer (2000) divides the studies on the determinants of social infrastructure in three groups. One focuses on incentives, and underlines the preference for dictators to build and maintain social infrastructure conducive to low average incomes. The second concerns the broad issue of cultural factors, encompassing religion, ethnic diversity, family structure and civic participation. The idea is that ethnic homogeneity, common religion and culture, in addition to civic participation increase social cohesion and trust. The latter seems to be crucial for the development of efficient financial markets. Finally, it has been identified an even more elusive concept of determinant of social infrastructure, namely individuals' beliefs about the right policies and institutions. Different individuals' beliefs imply different choices of institutions by governments.

All these three channels seem important for transition economies. Out of a common shift towards a more democratic society and a more liberalized economy, countries in transition have displayed a wide range of institutional arrangements and, for all of them, the process of institutional building takes a long time. A general problem encountered by transition economies has been the assumption of the existence of a blueprint of efficient institutions and the attempt to adopt it. The debate between gradualism and shock therapy is a case in point (Lipton and Sachs, 1990, Fischer and Gelb, 1991). The defenders of shock therapy neglected the importance of search and evolution of the right institutions for the different reality of each country (Rodrik, 2000). Furthermore, emphasis on the role of institutions implies a more complex view of the relationship between the state and the market. Indeed, the state plays a fundamental role in building institutions for the functioning of markets. Mario Nuti and Richard Portes (1993) point out the phenomenon of "state desertion" as a major drawback of reforms in transition economies. The collapse of the state apparatus might have been one of the main obstacles for the development of a well-functioning market economy. ${ }^{46}$ Therefore, the issue of the role of the state in connection with the development of social capital is a key area for research.

\footnotetext{
45 A growing literature is analyzing the role of institutions and of complementarity in institutions and institutional reform. See among others Paul Milgrom and John Roberts (1990), Ugo Pagano (1993) and Masahiko Aoki (2001). This literature points to interesting directions for research on transition countries as well. However, it goes beyond the scope of this paper.

${ }^{46}$ Boeri (2000) notes that employment in the state sector (excluding state enterprises) increased during the transition period in the more successful countries of CentratEastern Europe, while it fell in the less successful countries of the former Soviet Union.
} 
Furthermore, the role of social safety nets as a fundamental factor for generating social cohesion and support for market reforms cannot be underestimated. An additional important aspect in the analysis of institutions is the accession to European Union for several countries of Central and Eastern Europe. Indeed, in this case institutional change is by and large constrained to occur within the blueprint of the European Union. This would seem to collide with Rodrik's views on the need to learn and experiment with the right set of institutions for a specific country. However, it should be kept in mind that entry in the European Union is seen as one of the main objectives for the populations of CentratEastern European countries, and it is likely that individuals' beliefs are that European Union institutions represent the right institutions.

\section{Growth in Transition: The Empirical Literature}

The debate in the empirical literature on economic growth in transition economies has been mostly about establishing the relative importance of structural factors (broadly defined to include initial conditions) and policies (broadly defined to include both liberalization and macroeconomic policies) in explaining the output performance. In what follows, we provide a general overview of this cross-country literature. Because of the large number of individual country studies, we focus on cross-country studies, in particular, those paying attention not only to Central and Eastern Europe, but also to the former Soviet Union countries. Notice that this criterion excludes many important contributions. ${ }^{47}$

The cross-country literature focused on three main issues: the effect on growth of liberalization, macroeconomic adjustment (mainly inflation control), and initial conditions. Only a few exceptions discuss the impact of institutions on growth (Oleh Havrylyshyn and Ron van

\footnotetext{
${ }^{47}$ Eduardo Borenzstein and Peter Montiel (1992) and Jeffrey Sachs and Andrew Warner (1996) both examine only three transition countries. The former uses the augmented Solow framework to identify long term growth paths, while the latter uses three countries' experience to argue that harmonizing with the European Union policy standards will result in lower growth rates than following the policies of the group the authors define as "very fast growing developing economies." Another important study is Luca Barbone and Juan Zalduendo (1997), which estimates a model for a large sample of developing countries and then use the coefficients to discuss accession to the European Union of five Central and Eastern European countries. Edward Leamer and Mark Taylor (1994) provide a careful and original contribution that concludes with a number of hypothetical, although highly relevant scenarios, and the study by Vir Barta and Thomas Url (1996) examines five Central European transition countries. Individual country studies include, among others, Mark De Broeck and Kristina Kostial (1998) on Kazakhstan, Daniel Berkowitz and David DeJong (1998) and Irina Dolinskaya (1999) on Russia, De Broek and Koen (2000b)
} 
Rooden, 2000 and Martin Raiser, Christian Haerpfer, Thomas Nowotny and Claire Wallace, 2001).

\subsection{Liberalization and growth}

De Melo, Denizer and Gelb (1996) and De Melo and Gelb (1997) map the output decline, construct an index of the extent of liberalization and offer evidence that cumulative liberalization is closely related to the observed output dynamics. Because this liberalization index is used widely, we should note two of its distinguishing features. First, the index is based on the still controversial notion that what accounts for the disparity in economic performance during transition are government policies (De Melo and Gelb, 1997, pp. 62-63). Second, the index is a weighted-average of three components: liberalization of internal markets, of external markets and of private sector entry (weights are $0.3,0.3$ and 0.4 respectively). All indices incorporate a significant dose of arbitrariness and judgement on the part of the researchers who built them. Even abstracting from the problem of the quality of the measures of liberalization, an important issue debated in the literature is whether liberalization has an impact on output performance through the cumulative level of liberalization achieved or through the change in liberalization indexes. In other words, there is an issue on the time dimension of the relationship between liberalization and growth. If one considers the cumulative index the effects of liberalization do not disappear after the current period.

Fischer, Sahay and Vegh (1996a) use the De Melo et al. liberalization indexes in a panel of 20 transition countries (for 1992-1994). They find that growth is positively and statistically significantly associated with fiscal surpluses, foreign aid, and the extent of liberalization, and is negatively and significantly associated with inflation. In subsequent work (1996b), the authors increase the number of countries (from 20 to 25, for 1992-1994) to conclude that growth is negatively and significantly associated with initial income, and positively and significantly associated with the choice of exchange rates regimes, fiscal surpluses, and the (cumulative) liberalization index. Fischer, Sahay and Vegh (1998) quantify the income losses incurred during the socialist period: using 1937 data for 6 countries, they estimate that approximately two-thirds of GDP per capita were lost during the socialist experiment.

on Poland, and Jeremin Zettlemeyer (1998) on Uzbekistan. 


\section{William Davidson Institute Working Paper 470}

Anders Åslund, Peter Boone and Simon Johnson (1996) find that conclusions about the impact of macroeconomic policies change dramatically when considering output change (between 1989 and 1995) instead of output level at the end of the period (1995). For the first case, they report that once dummy variables for ruble zone and war-torn countries are included, "there is no robust significant correlation between output change and any measure of reform" (1996, p. 233). However, when they turn their attention to output levels in 1995, the extent of liberalization and inflation are found to be statistically significant and have the expected signs.

\subsection{Initial conditions and policies}

Denizer (1997) stresses the role of initial conditions and in doing so provides a finer depiction of the determinants of the various "transition patterns" identified in De Melo, Denizer and Gelb (1996). He finds that initial conditions matter, as proxied by distance from Vienna and whether the country was independent before socialism. Besides the degree of arbitrariness in the choice of the relevant variables used as initial conditions, there is the issue of correlation between initial conditions and liberalization measures. One can argue that the extent of liberalization and the speed of reform is not independent of initial conditions. This is another instance in which existing empirical work is not derived from an underlying theory. In this regard, Berta Heybey and Peter Murrell (1997) identify a set of problems in the existing literature, notably with respect to the measurement of the speed of reform and the issue of simultaneity between output performance and reform policies. They tackle the problem by using a simultaneous equations approach, and conclude that initial conditions are "much more important than policy variables in determining growth performance" (1997, p. 15).

The debate on the relative importance of economic policies and initial conditions is likely to continue for some time. ${ }^{48}$ On the one hand, there is evidence that policies are instrumental in explaining the recovery as argued by, among others, Marcelo Selowsky and Ricardo Martin (1997), Berg, Borenzstein, Sahay and Zettlemeyer (1999) and Oleh Havrylyshyn, Thomas Wolf, Julian Berengaut, Marta Castello-Branco, Ron van Rooden and Valerie Mercer-Blackman (1999). ${ }^{49}$ On the other hand, Gary Krueger and Marek Ciolko (1998) and Vladimir Popov

\footnotetext{
${ }^{48}$ Further, we must note the increasing attention political factors have received recently in this debate. See Castanheira and Popov (2000), Jan Fidrmuc (2000), and Roland (2000).

${ }^{49}$ Holger Wolf (1999) argues that liberalization is associated with the output fall and recovery.
} 
(1999), among others, provide evidence that the impact of liberalization becomes insignificant once initial conditions are accounted for.

One of the main results achieved in the papers arguing on the dominant role of policies is that reform measures have an initial negative impact on growth but over time they determine positive growth, overcoming the initial adverse effect. Havrylyshyn et al. (1999) conclude this by inserting lagged values of the reform indices in addition to the contemporaneous one. However, the opposite sign, and the similar magnitude, of the coefficients of contemporaneous and lagged reform indicators may simply reflect a problem of collinearity. The reform indicators are cumulative indices and thus are surely highly correlated over time.

\subsection{Asymmetric growth of state and private sectors}

Despite the central role that the asymmetric behavior of state and private sectors play in the theories of optimal speed of transition, most empirical analyses have focused on aggregate variables. The major obstacle for a disaggregated analysis is the lack of reliable data on private sector activity. Nevertheless, there are a few exceptions in the empirical literature that try to test a model that takes into account the reallocation of resources from state to private sectors. Ernesto Hernandez-Cata (1997) puts forward a model of the transition that focuses on the reallocation of capital (from the state to the private sector), and relates the output fall to liberalization and stabilization. He also presents empirical results that support the view that the transition is to take considerable time as it involves, fundamentally, the restructuring of the inherited capital stock. In addition, his results confirm a strong association between price stabilization and the resumption of growth. Of particular interest is the finding that the much worse performance of former Soviet Union countries vis-à-vis those of Central and Eastern Europe, dissipate after controlling for the timing and intensity of liberalization, price stabilization and under-reporting of output. 


\section{William Davidson Institute Working Paper 470}

\subsection{Institutions and growth}

As noted earlier the role of institutions has been largely neglected in the empirical analysis of growth in transition economies. However a few exceptions are noteworthy. In particular, two recent papers by Havrylyshyn and van Rooden (2000) and by Raiser et al. (2001) represent first attempts to provide a comprehensive study of the role of institutions on economic performance in transition economies. However, both studies remain valuable initial attempts, but are still far from a robust analysis of the relationship between institutions and growth in economies in transition.

The paper by Havrylyshyn and van Rooden update their previous regressions on panel data for the period 1991-98 to include institutional variables. Nine institutional variables from five different sources are used. Because of the high degree of correlation among different variables, the authors used a principal component analysis. It turns out that the first principal component explains about 90 percent of overall variability of 8 institutional indices. Inclusion of the institutional variable adds to the explanation of growth, although its contribution is small compared to structural reform and initial conditions. A few cautioning notes are in order. First, institutional variables concern 1997, that is one of the last years of the sample. Second, institutional indicators are highly subjective. This comes out clearly if one looks at the correlations between different institutional indicators, correlations that are extremely high. One would certainly expect some correlations among these variables, however such high degree of correlation between legal, economic and political institutions is suspicious. Finally, the idea that institutional development has an immediate impact on growth, without attention to the possible time dimension of the relationship is striking in a regression in which the authors include a dynamic structure for the structural reform indicators. What does the level of institutional development in 1997 tell us about growth rates during the period 1990-98? Perhaps the authors assume that the cross-country variation in institutional development observed in 1997 is similar to the one observed throughout the period. Despite a valuable effort to collect data on institutional development, the work appears only a starting point in the analysis of institutions and growth in transition economies.

Similar comments apply to Raiser et al. (2001), who find some, though rather weak, evidence of positive impact of social capital on growth performance in transition economies. An interesting result is that social capital has a significant impact on growth, especially civic participation and trust in public institutions (especially the legal system and police), while reform 
variables are not statistically significant. Interacting reform indicators and social capital to test whether reform are effective when social capital is sufficiently developed does not lead to significant results. However, much more work is needed.

Perhaps, rather than continuing to rely on unnecessarily subjective reform indicators, more attention should be given to more objective measures such as financial development and specific policies aimed at improving the functioning of a market economy. Much of the empirical work carried out on transition economies is inevitably exploratory. There is a growing consensus on the importance of institutions. However, the channels through which institutions affect growth are not well understood. The time dimension of the relationship between institutions and growth is also still unclear. In light of the theoretical work discussed earlier it would be interesting to test the impact of institutional change, not only the impact of levels of institutional development. Because of the short time interval available for the empirical analysis it would seems reasonable to concentrate on the relationship between initial level of institutional development and economic performance. In particular, as underlined by the theoretical work, the effects of liberalization policies and of macroeconomic measures likely depend on such different initial level of institutional development. Interacting institutional variables with liberalization and macroeconomic policy measures seems a very promising research agenda. ${ }^{50}$ In carrying out such an analysis one should also consider the endogeneity of reform measures, both in connection with economic performance and institutional development. Such endogeneity problems are discussed in the political economy literature (Roland, 2000, Castanheira and Popov, 2000).

Similarly, the role of social safety nets as a fundamental institution for the functioning of a market economy, especially in a period of rapid structural change, should be tackled in the empirical analysis. ${ }^{51}$

\subsection{Growth prospects}

Finally, there is another worth mentioning strand of this empirical literature that discusses the growth prospects for economies in transition. One of the main findings of this literature is

\footnotetext{
${ }^{50}$ Coricelli and Campos (2000) present a preliminary test of these interactions, finding some significant results on the dependence of the effects of reform policies on initial conditions and on institutional development.

${ }^{51}$ Coricelli and Campos (2000) find a significant and positive impact of social expenditures on growth in
} 


\section{William Davidson Institute Working Paper 470}

instrumental because it establishes empirically that the underlying long-run trends are significantly different before and after 1989. ${ }^{52}$ Using traditional growth equations (Barro, 1991, and Ross Levine and David Renelt, 1992) to extrapolate growth prospects of transition economies would lead to reasonably optimistic forecast, even though no "miracle" is foreseen. Indeed, growth rates are projected to hover at around 5 percent, that would imply a rather slow process of convergence to not only average income of European Union countries, but even to low income European countries like Greece, Portugal and Spain (Fischer et al., 1998).

Among the favorable factors fostering growth one can identify human capital development, although the caveats noted above apply. In the Barro specification, government consumption, that is rather high in transition economies, adversely affect growth. In light of the review of theories of previous sections, a fundamental factor that can hamper the process of convergence is the level of institutional development. Using Phil Keefer and Steve Knack (1995) specification, the EBRD Transition Report of 1997 concluded that growth prospects would be significantly reduced. Such a conclusion is reached by comparing findings on future growth in transition countries (from Levine-Renelt specifications) with those from an alternative specification that includes an index of institutional development. ${ }^{53}$ This comparison suggests a downward revision of the estimated long-run growth trend: even for those transition economies with relatively high-quality institutions (and for which, institutional data are available), the absence of further institutional change should, according to those calculations, lower long-term growth rates by 1.5 percentage points.

\section{Conclusion}

Transition is the simultaneous change in economic structures and institutions and the final outcome crucially depends upon the coherence between economic reform in terms of liberalization of goods and factor markets, macroeconomic policies and institutional development. The collapse of output in Central-Eastern Europe and especially the Former Soviet

transition economies.

52 This literature includes Denizer (1997), Peter Havlik (1996), and Fischer, Sahay and Vegh (1997, 1998).

53 This is a composite index encompassing "expropriation risk", "rule of law", "risk of contract repudiation by the government", "corruption", and "quality of the bureaucracy" (EBRD, 1997, p. 106). The enlarged Levine-Renelt specification includes enrollment rates in primary school, changes in international prices, and growth of labor force (instead of population). 


\section{William Davidson Institute Working Paper 470}

Union indicated a lack of coherence in the reform strategies. In general, more attention to a comparative analysis of the experience of China could prove useful. Initial conditions and economic structure were sharply different in China. However, reform strategies differed as well. Therefore, the comparison with China highlights one of the main lessons that can be drawn from the first ten years of transition, namely that reform strategies cannot neglect the different institutional structures.

From our review, a few suggestions for future research stand out.

First, the list of stylized facts we offer are based on data currently available. We highlighted the limitations of these data series, both in terms of completeness and accuracy. A fundamental direction for future research is to try to validate these facts. More work should be devoted to examine the limitations and inadequacies of the various time series needed to study growth in the early transition years. For instance, re-calculations or re-valuations of the capital stocks are needed and in doing so, it is important to disentangle the roles of public and private investment. There should also be attempts to improve the available series on labor. In particular, future research should go beyond the number of workers and years of schooling and try to provide a more economically meaningful picture of the contribution of labor (specifically, in terms of hours worked and effective use of skills). More reliable estimates of physical, human capital and labor contributions to growth will improve our understanding of the sources of this process and the relative roles of various crucial factors.

Second, research should focus more on institutions, including the role and size of the government. A clear specification of the channels through which institutions affect growth is needed. In this respect, a particularly relevant area for research should be the role of institutions for the development of financial markets. This extends beyond pure conceptual pursuits. Data on institutions based on objective criteria is also highly desirable. A last concern is the emphasis on cross-sectional data that we deem mistaken. Transition is a dynamic process and a crucial aspect of it has been the dynamics of institutional reform. The empirical efforts that attempt to put forward cross-sectional time series data on institutions in transition are few and admittedly crude at this point. One crucial suggestion for future research is to change this situation.

Third, relevant measures of initial conditions should be provided. Moreover, it should be studied how they relate to degrees of distortions across sectors, across countries and over time.

Fourth, more emphasis should be placed upon a better understanding of the role of economic reforms and reform strategies in dictating the path of the transition process. This 
should be pursued both conceptually and empirically. There are a number of theoretical models that stress the role of reform strategies. Yet the data for discriminating among these models is lacking. The few indicators available are unnecessarily subjective and more often than not the needed documentation on their construction is not disclosed.

Last, but not least, the transition experience raises simultaneously many new challenges to the conceptual frames we use to study economic growth and development. One key example of these new challenges are isolating reallocation (its sources and effects) from accumulation and technological progress. 


\section{References}

Acemoglu, Daron; Simon Johnson and James Robinson. 2001. "The Colonial Origins of Comparative Development: An Empirical Investigation," Amer. Econ. Rev. 91: 5, pp. 1369-1401.

Aghion, Philippe and Olivier Blanchard. 1994. "On the Speed of Transition in Central Europe," in NBER Macroeconomics Annual 1994. Stanley Fischer and Julio Rotemberg, eds. Cambridge: MIT Press, pp. 283-320.

Aghion, Philippe and Peter Howitt. 1998. Endogenous Growth Theory, Cambridge: MIT Press.

Alesina, Alberto and Roberto Perotti, 1996. "Fiscal Adjustments in OECD Countries: Composition and Macroeconomic Effects," NBER Working Paper 5730.

Alesina, Alberto and Eliana La Ferrara. 2000. "The Determinants of Trust," NBER Working Paper 7621.

Aoki, Masahiko. 2001. Toward a Comparative Institutional Analysis, Cambridge: MIT Press.

Ark, Bart van. 2001. "Comparative Patterns of Growth and Stagnation: East and West Europe Considered," mimeo, U. Groningen.

Åslund, Anders; Peter Boone and Simon Johnson. 1996. "How to Stabilize: Lessons from Postcommunist Countries", Brookings Pap. Econ. Act. 1, pp. 217-91.

Baffes, John and Anwar Shah, 1998. "Productivity of Public Spending, Sectoral Allocation Choices, and Economic Growth," Econ. Devel. Cul. Change 46: 2, pp. 291-303.

Baily, Martin and Alok Chakrabarti, 1988. Innovation and the Productivity Crisis, Washington DC: Brookings Institution.

Baldwin, Robert. 1994. Towards an Integrated Europe, London: CEPR.

Barbone, Luca and Juan Zalduendo. 1997. "EU Accession and Economic Growth: The Challenge for Central and Eastern European Countries," World Bank Policy Research Working Paper 1721.

Barro, Robert. 1991. "Economic Growth in a Cross Section of Countries," Quart. J. Econ. 106: 2, pp. 407-44.

Barro, Robert. 1999. "Notes on Growth Accounting”, J. Econ. Growth 4:2, pp. 119-37.

Barro, Robert and Xavier Sala-i-Martin, 1995. Economic Growth. NY: McGraw-Hill.

Barro, Robert and Jong-Wha Lee. 2001. "International Data on Educational Attainment: Updates and Implications," Oxford Econ. Pap. 53:3, pp. 541-63. 


\section{William Davidson Institute Working Paper 470}

Barta, Vit and Thomas Url. 1996. Growth Perspectives of Five Central European Transition Countries, Vienna: WIFO.

Bartholdy, Kasper. 1997. "Old and New Problems in the Estimation of National Accounts in Transition Economies", Econ. Transition 5:1, pp.131-46.

Belkindas, Misha and Olga Ivanova. 1995. Foreign Trade Statistics in the USSR and Successor States, Washington DC: World Bank.

Berg, Andrew and Jeffrey Sachs. 1992. "Structural Adjustment and International Trade in Eastern Europe: The Case of Poland," Econ. Pol.: A Europ. Forum 14, pp. 117-73.

Berg, Andrew; Borenzstein, Eduardo, Sahay, Ratna and Jeromin Zettelmeyer, 1999. "The Evolution of Output in Transition Economies: Explaining the Differences," IMF Working Paper 99/73.

Bergson, Abram. 1991. "The U.S.S.R. before the Fall: How Poor and Why?" J. Econ. Perspect. 5:4, pp. 29-44.

Berkowitz, Daniel and David DeJong. 1998. "Accounting for Growth in Post-Soviet Russia," William Davidson Institute Working Paper 127.

Bernard, Andrew and Charles Jones. 1996. "Productivity Across Industries and Countries: Time Series Theory and Evidence," Rev. Econ. Statist. 78:1, pp. 135-46.

Blanchard, Olivier. 1997. The Economics of Post-Communist Transition, Oxford: Clarendon Press.

Blanchard, Olivier; Rudiger Dornbusch, Paul Krugman, Richard Layard and Lawrence Summers. 1991. Reform in Eastern Europe, Cambridge: MIT Press.

Blanchard, Olivier and Michael Kremer. 1997. "Disorganization," Quart. J. Econ. 112:4, pp. 1091-1126.

Boeri, Tito. 2000. Structural Change, Welfare Systems, and Labour Reallocation: Lessons from The Transition of Formerly Planned Economies, Oxford: Oxford U. Press.

Boeri, Tito and Christopher Flinn. 1999. "Returns to Mobility in the Transition to a Market Economy," J. Compar. Econ. 27:1, pp. 4-32.

Boeri, Tito and Katherine Terrell. 2002. "Institutional Determinants of Labor Reallocation in Transition," J. Econ. Perspect., 16 :2, forthcoming.

Borenzstein, Eduardo and Peter Montiel. 1992. "Savings, Investment and Growth in Eastern Europe", in Central and Eastern Europe: Roads to Growth. George Winkler, ed. Washington DC: International Monetary Fund, pp. 153-158. 
Brainerd, Elizabeth. 1998. "Winners and Losers in Russia’s Economic Transition," Amer. Econ. Rev. 88:5, pp. 1094-1116.

Brainerd, Elizabeth. 2001. "Death and the Market," mimeo, Williams College.

Brainerd, Elizabeth, Kawachi, Ichiro and Bruce Kennedy. 1998. "The Role of Social Capital in the Russian Mortality Crisis," World Dev. 26:11, pp. 2029-43.

Brandt, Loren and Xiaodong Zhu. 2000. "Redistribution in a Decentralized Economy: Growth and Inflation in China under Reform," J. Pol. Economy 108:2, pp. 422-39.

Brenton, Paul and Daniel Gros. 1997. "Trade Reorientation and Recovery in Transition Economies," Oxford Rev. Econ. Pol. 13:2, pp. 65-76.

Caballero, Ricardo and Mohamad Hammour. 1996. "On the Ills of Adjustment," J. Dev. Econ., 51: 1, pp. 161-92.

Calvo, Guillermo and Fabrizio Coricelli. 1992. "Stabilizing a Previously Centrally Planned Economy: Poland 1990," Econ. Pol.: A Europ. Forum 14, pp. 213-26.

Calvo, Guillermo and Fabrizio Coricelli. 1993. "Output Collapse in Eastern Europe: The Role of Credit”, IMF Staff Pap. 40:1, pp. 32-52.

Calvo, Guillermo and Fabrizio Coricelli. 1996. "Credit Market Imperfections and Low-Output Equilibria in Economies in Transition," in Financial Factors in Economic Stabilization and Growth. Mario Blejer, Zvi Eckstein, Zvi Hercowitz and Leonardo Leiderman, eds. Cambridge: Cambridge U. Press, pp. 75-102.

Calvo, Guillermo and Jacob Frankel. 1991. "Credit Markets, Credibility and Economic Transformation," J. Econ. Perspect. 5:4, pp. 139-148.

Calvo, Guillermo and Carlos Vegh. 1993. "Exchange-Rate-Based Stabilization under Imperfect Credibility," Proceedings from IEA Conference on Open-Economy Macroeconomics. Helmut Frisch and Andreas Woergotter, eds. London: McMillan, pp. 3-28.

Campos, Nauro. 2000. "Context is Everything: Measuring Institutional Change in Transition Economies,” World Bank Policy Research Working Paper 2269.

Campos, Nauro and Aurelijus Dabušinskas. 2001. "So Many Rocket Scientists, So Few Marketing Clerks: Determinants of Occupational Change During The Estonian Transition," CERGE-EI Discussion Paper 59.

Campos, Nauro and Yuko Kinoshita. 2001. "Foreign Direct Investment as Technology Transferred: Some Panel Evidence from the Transition Economies," mimeo, U. Newcastle.

Campos, Nauro and Dana Zlabkova. 2001. "The Wrong Mix: A First Look at Occupational Mobility during the Hungarian Transition," CERGE-EI Discussion Paper No. 52. 
Castanheira, Micael and Vladimir Popov. 2000. "Political Economy of Growth in Transition Countries," mimeo, ECARES.

Castanheira, Micael and Gérard Roland. 2000. "The Optimal Speed of Transition: A General Equilibrium Analysis", Int. Econ. Rev. 41:1, pp. 219-39.

Chadha, Bankhim and Fabrizio Coricelli. 1995. "Unemployment, Investment and Sectoral Reallocation," CEPR Discussion Paper 1110.

Chadha, Bankhim and Fabrizio Coricelli. 1997. "Fiscal Constraints and the Speed of Transition," J. Dev. Econ. 52:1, pp. 219-247.

Chadha, Bankhim, Fabrizio Coricelli and Kornélia Krajnyak. 1993. "Economic Restructuring, Unemployment, and Growth in a Transition Economy," IMF Staff Pap. 40: 4, pp. 744-80 .

Chenery, Hollis, 1960. "Patterns of Industrial Growth,” Amer. Econ. Rev. 50: 4, pp. 624-654.

Chow, Gregory. 1983. "Capital Formation and Economic Growth in China," Quart. J. Econ. 108:3, pp. 809-42.

Christofferson, Peter, and Peter Doyle, 1998. "From Inflation to Growth: Eight Years of Transition, " IMF Working Paper 98/100.

Chu, Ke-young and Gerd Schwartz. 1994. "Output Decline and Government Expenditures in European Transition Economies”, IMF Working Paper 94/68.

Commander, Simon and Fabrizio Coricelli, eds. 1995. Unemployment, Restructuring, and the Labor Market in Eastern Europe and Russia, Washington DC: World Bank.

Coricelli, Fabrizio. 1997. "Fiscal Policy: A Long-Term View," in Fiscal Policy in Transition. Lorand Ambrus-Lakatos and Mark Schaffer, eds. London: CEPR-IEWS, pp. 39-52.

Coricelli, Fabrizio. 1998. Macroeconomic Policies and the Development of Markets in Transition Economies, Budapest: CEU Press.

Coricelli, Fabrizio and Nauro Campos. 2000. "A Tale of Two Satellites: An Empirical Analysis of Growth in Transition Economies," mimeo, U. Siena.

Dabrowski, Marek. 1997. "Dynamics of Fiscal Developments During Transition," in Fiscal Policy in Transition. Lorand Ambrus-Lakatos and Mark Schaffer, eds. London: CEPR-IEWS, pp. 3-15.

Dawkins, Christina and John Whalley. 1996. "Economic Reform and Performance in Vietnam" in Reforming Asian Socialism: The Growth of Market Institutions. John McMillan and Barry Naughton, eds. Ann Arbor: U. Michigan Press, pp. 297-316. 
De Broeck, Mark and Kristina Kostial. 1998. "Output Decline in Transition: The Case of Kazakhstan," IMF Working Paper 98/45.

De Broek, Mark and Vincent Koen. 2000a. "The 'Soaring Eagle': Anatomy of the Polish TakeOff in the 1990s," IMF Working Paper 00/6.

De Broek, Mark and Vincent Koen. 2000b. "The Great Contractions in Russia, the Baltics and the Other Countries of the former Soviet Union: A View from the Supply Side," IMF Working Paper 00/32.

De Melo, Martha, Cevdet Denizer, and Alan Gelb. 1996. "From Plan to Market: Patterns of Transition", World Bank Econ. Rev 10: 3, pp. 397-424.

De Melo, Martha, Cevdet Denizer, Alan Gelb and S. Tenev. 1997. "Circumstance and Choice: The Role of Initial Conditions and Policies in Transition Economies," World Bank Policy Research Working Paper 1866.

De Melo, Martha and Alan Gelb. 1997. "Transition to Date: A Comparative Overview", in Lessons from the Economic Transition: Central and Eastern Europe in the 1990s. Salvatore Zecchini, ed. Dordrecht: Kluwer, pp. 59-78.

Denizer, Cevdet. 1997. "Stabilization, Adjustment, and Growth Prospects in Transition Economies", World Bank Policy Research Working Paper 1855.

Devarajan, Shantayanan; Vinaya Swaroop and Heng-fu Zou. 1996. "The Composition of Public Expenditure and Economic Growth," J. Monet. Econ. 37: 3, pp. 313-44.

Dewatripont, Mathias and Gérard Roland. 1997. "Transition as a Process of Large Scale Institutional Change," in Advances in Economics and Econometrics: Theory and Applications (Volume II). David Kreps and Kenneth Wallis, eds. Cambridge: Cambridge U. Press, pp. 240278.

Dolinskaya, Irina. 1999. "Explaining Russian Output Collapse: Aggregate Sources and Regional Evidence," mimeo, Cambridge U.

Döhrn, Roland and Ullrich Heilemann. 1996. "The Chenery Hypothesis and Structural Change in Eastern Europe," Econ. Transition 4:2, pp. 411-23.

Durlauf, Steven, and Quah, Danny. 1999. "The New Empirics of Economic Growth" in Handbook of Macroeconomics (Vol. 1A). John Taylor and Michael Woodford, eds. Amsterdam: Elsevier, pp. 235-308.

Easterly, William and Sergio Rebelo. 1993. "Fiscal Policy and Economic Growth: An Empirical Investigation" J. Monet. Econ. 32:3, pp. 417-58.

Easterly, William and Stanley Fischer. 1995. "The Soviet Economic Decline”, World Bank Econ. Rev. 9: 3, pp. 341-71. 
Ericsson, Richard. 1991. "The Classical Soviet-Type Economy: Nature of the System and Implications for Reform," J. Econ. Perspect. 5:4, pp. 11-28.

Estrin, Saul and Giovanni Urga. 1997. "Testing for Ongoing Convergence in Central and Eastern Europe, 1970-95”, CEPR Discussion Paper 1616.

European Bank for Reconstruction and Development, various years. Transition Report, London: European Bank for Reconstruction and Development [EBRD].

Fidrmuc, Jan. 1999. "Liberalization, Democracy and Economic Performance during Transition," mimeo, ZEI.

Filer, Randall, Thorvaldur Gylfason, Stepan Jurajda and Janet Mitchell. 2000. "Markets and Growth in the Post-Communist World," mimeo, CERGE-EI.

Fischer, Stanley and Alan Gelb. 1991. "The Process of Socialist Economic Transformation," J. Econ. Perspect. 5:4, pp. 91-105.

Fischer, Stanley, Ratna Sahay and Carlos Vegh. 1996a. "Economies in Transition: The Beginnings of Growth", Amer. Econ. Rev. (Papers and Proceedings) 86: 2, pp. 229-233.

Fischer, Stanley, Ratna Sahay and Carlos Vegh. 1996b. "Stabilization and Growth in Transition Economies: The Early Experience", J. Econ. Perspect. 10:2, pp.45-66.

Fischer, Stanley, Ratna Sahay and Carlos Vegh. 1997. "From Transition to Market: Evidence and Growth Prospects", in Lessons from the Economic Transition: Central and Eastern Europe in the 1990s. Salvatore Zecchini, ed. Dordrecht: Kluwer, pp. 79-101.

Fischer, Stanley, Ratna Sahay and Carlos Vegh. 1998. "How Far is Eastern Europe from Brussels?" IMF Working Paper 98/53.

Flemming, John and John Micklewright. 1999. "Income Distribution, Economic Systems and Transition,” UNICEF Innocenti Occasional Paper 70.

Frydman, Roman; Stanislaw Wellisz and GREG Kolodko. 1991. "Stabilization Policies in Poland: A Progress Report", in Exchange Rate Policies in Developing and Post-Socialist Countries. Emil-Maria Claassen, ed. San Francisco: ICS, pp. 89-115.

Gaddy, Clifford and Barry Ickes. 1998. "Beyond a Bail Out: Time to Face Reality about Russia's 'Virtual Economy'," mimeo, Brookings Institution.

Garvy, George, "The Monetary System and Payments Flow." in Alec Nove, and Mario Nuti (eds.) Socialist Economies: Selected Readings, New York: Penguin Books, 1972, pp. 275-306.

Gomulka, Stanislaw. 1998. "Output: Causes of the Decline and Recovery," CASE-CEU Working Paper 8. 
Guriev, Serguei and Barry Ickes. 2000. "Microeconomic Aspects of Economic Growth in Eastern Europe and the former Soviet Union: 1950-2000," William Davidson Institute Working Paper 348.

Gylfason, Thorvaldur. 2000. "Resources, Agriculture, and Economic Growth in Economies in Transition," Kyklos 53:4, pp. 545-80.

Harrison, Mark. 1998. "Trends in Soviet Labour Productivity, 1928-1985: War, Postwar Recovery, and Slowdown," Europ. Rev. Econ. Hist., 2, pp. 171-200.

Havlik, Peter. 1996. "Stabilization and Prospects for Sustainable Growth in the Transition Economies", in Economies of Transition: Structural Adjustment and Growth Prospects in Eastern Europe. Mark Knell, ed. Aldershot, England: Edward Elgar, pp. 25-48.

Havrylyshyn, Oleh and Hassan Al-Atrash. 1998. "Opening Up and Geographic Diversification of Trade in Transition Economies," IMF Working Paper 98/22.

Havrylyshyn, Oleh and Ron van Rooden, 2000. "Insitutions Matter in Transition, but so do Policies," IMF Working Paper 00/70.

Havrylyshyn, Oleh, Wolf, Thomas, Berengaut, Julian, Castello-Branco, Marta, van Rooden, Ron and Valerie Mercer-Blackman, 1999. "Growth Experience in Transition Countries: 1990-98," IMF Occasional Paper 184.

Hernandez-Cata, Ernesto. 1997. "Liberalization and the Behavior of Output during the Transition from Plan to Market," IMF Staff Pap. 44: 4, pp. 405-29.

Heybey, Berta and Peter Murrell. 1997. "The Relationship between Economic Growth and the Speed of Liberalization During Transition", mimeo, U. Maryland.

Holmes, Kim; Bryan Johnson and Melanie Kirkpatrick, eds, 1997. The 1997 Index of Economic Freedom. NY: Heritage Foundation.

Holmes, Kim; Bryan Johnson and Melanie Kirkpatrick, eds, 1998. The 1998 Index of Economic Freedom. NY: Heritage Foundation.

Johnson, Simon; Daniel Kaufmann and Andrei Shleifer. 1997. "The Unofficial Economy in Transition," Brookings Pap. Econ. Act. 2, pp. 159-221.

Kalra, Sanjay and Torsten Slok. 1999. "Inflation and Growth in Transition: Are the Asian Economies Different?" IMF Working paper 99/118.

Kaminski, Bartlomiej; Zhen Wang and Alan Winters. 1996. Foreign Trade in the Transition: The International Environment and Domestic Policy, Washington DC: World Bank. 
Karatnycky, Adrian; Alexander Motyl and Boris Shor. 1998. Nations in Transit 1997: Civil Society, Democracy and Markets in East Central Europe and the Newly Independent States, New Brunswick: Transaction Publishers.

Keefer, Phillip and Steve Knack. 1995. "Institutions and Economic Performance: Cross Country Tests Using Alternative Institutional Measures,” Econ. Politics 7:3, pp. 207-27.

Kiguel, Miguel and Nissan Liviatan. 1989. "The Business Cycle Associated with ExchangeRate-Based Stabilizations," mimeo, World Bank.

Kornai, János. 1992. The Socialist System: The Political Economy of Communism, Princeton: Princeton U.Press.

Kornai, János. 1994. "Transformational recession: The main causes”, J. Compar. Econ. 19:3, pp. 39-63.

Kornai, János. 1995. "The Postsocialist Transition and the State: Reflections in the Light of Hungarian Fiscal Problems", in Highways and Byways: Studies on Reform and Postcommunist Transition. Cambridge: MIT Press.

Kornai, János, 2000. "Ten Years After 'The Road to a Free Economy', The Author SelfEvaluation,” mimeo, Harvard U.

Krueger, Gary and Marek Ciolko. 1998. "A Note on Initial Conditions and Liberalization during Transition,” J. Compar. Econ. 26:4, pp. 718-34.

Lau, Lawrence, Qian, Yingyi and Gérard Roland. 2000. "Reform without Losers: An Interpretation of China's Dual-Track Approach to Transition". J.Pol.Economy 108:1,pp. 120-43.

Leamer, Edward and Mark Taylor. 1994. "The Empirics of Economic Growth in Previously Centrally Planned Economy”, CEPR Discussion Paper 976.

Lehmann, Hartmut, Jonathan Wadsworth and Alessandro Acquisti, 1999. "Grime and Punishment: Employment, Wages and Wage Arrears in the Russian Federation," J. Comparat. Econ. 27: 4, pp 595-617.

Levine, Ross and David Renelt. 1992. "A Sensitivity Analysis of Cross-Country Growth Regressions", Amer. Econ. Rev. 82:4, pp. 942-63.

Lipton, David and Jeffrey Sachs. 1990. "Creating a Market Economy in Eastern Europe: The Case of Poland," Brookings Pap. Econ. Act. 1, pp. 75-133.

Lucas, Robert E., Jr. 1988. “On the Mechanics of Economic Development," J. Monet. Econ. 22 (July), pp. 3-42.

Marin, Dalia and Monika Schnitzer. 1999. "Disorganization and Financial Collapse," CEPR Discussion Paper 2245. 
Maurel, Mathilde and Guillaume Cheikbossian. 1997. "The New Geography of East European Trade", CEPR Discussion Paper 1580.

McKinnon, Ronald. 1991. The Order of Economic Liberalization: Financial Control in the Transition to a Market Economy. Baltimore: John Hopkins U. Press.

McMillan, John. 1997. "Markets in Transition," in Advances in Economics and Econometrics: Theory and Applications. David Kreps and Kenneth Wallis, eds. Cambridge: Cambridge U. Press, pp. 210-239.

McMillan, John and Barry Naughton. 1992. "How to Reform a Planned Economy: Lessons from China," Oxford Review of Econ. Pol. 8:1, pp. 130-43.

McMillan, John; Simon Johnson, Daniel Kaufmann and Christopher Woodruff. 2000. "Why Do Firms Hide? Bribes and Unofficial Activity After Communism," J. Pub. Econ. 76:3, pp. 495520.

Milanovic, Branko. 1998. Income, Inequality, and Poverty during the Transition from Planned to Market Economy, Washington DC: World Bank.

Milgrom, Paul and John Roberts. 1990. "The Economics of Modern Manufacturing: Technology, Strategy, and Organization," American Ec. Review. 80:3, pp. 511-528.

Miller, Stephen and Frank Russek. 1997. "Fiscal Structures and Economic Growth," Econ. Inquiry 35:3, pp. 603-13.

Murrell, Peter. 1995. “The Transition According to Cambridge, Massachusetts," J. Econ. Lit. 33:1, pp. 164-78.

Naughton, Barry. 1995. Growing out of the Plan: Chinese Economic Reform 1978-1993, Cambridge: Cambridge U. Press.

Naughton, Barry. 1996. "Distinctive Features of Economic Reform in China and Vietnam," in Reforming Asian Socialism: The Growth of Market Institutions, John McMillan and Barry Naughton, eds. Ann Arbor: U. of Michigan Press.

Nuti, Mario and Richard Portes. 1993. "Central Europe: The Way Forward", in Economic Transformation in Central Europe: A Progress Report. Richard Portes, ed. London: CEPR, pp. $1-20$.

Ofer, Gur. 1987. “Soviet Economic Growth: 1928-85,” J. Econ. Lit. 25: 4, pp. 1767-1833.

Pagano, Ugo 1993. "Organizational Equilibria and Institutional Stability," in Democracy and Markets: Participation, Accountability, and Efficiency, Samuel Bowles, Herbert Gintis and Bo Gustafsson eds. Cambridge: Cambridge U. Press, pp. 86-114. 
Popov, Vladimir. 1999. "Shock Therapy versus Gradualism: Explaining the Magnitude of the Transformational Recession," mimeo, Carleton U.

Qian, Yingyi. 2000. "The Process of China's Market Transition (1978-1998): The Evolutionary, Historical, and Comparative Perspectives." J. Inst. Theoretical Econ. 156:1, pp. 151-71.

Qian, Yingyi and Gérard Roland. 1998. "Federalism and the Soft Budget Constraint". Amer. Econ. Rev. 88:5, pp. 1143-62.

Qian, Yingyi; Gérard Roland and Chenggang Xu. 1999. "Why is China different from Eastern Europe? Perspectives from Organization Theory," Europ. Econ. Rev. 43:4-6, pp. 1085-94.

Raiser, Martin; Christian Haerpfer, Thomas Nowotny and Claire Wallace. 2001."Social Capital in Transition: A First Look at the Evidence," EBRD Working Paper 61.

Riedel, James and Bruce Comer. 1997. "Transition to a Market Economy in Viet Nam," in Economies in Transition: Comparing Asia and Eastern Europe. Wing Woo, Stephen Parker and Jeffrey Sachs, eds. Cambridge: MIT Press, pp. 189-216.

Rodrik, Dani. 2000. "Institutions for High-quality Growth: What They Are and How to Acquire Them," NBER Working Paper 7540.

Roland, Gérard. 2000. Transition and Economics: Politics, Firms, Markets, Cambridge: MIT Press.

Roland, Gérard and Thierry Verdier. 1997. “Transition and The Output Fall”, CEPR Discussion Paper 1636.

Romer, David. 2000. Advanced Macroeconomics, Second Edition, NY: McGraw-Hill.

Rostowski, Jacek. 1997. “Comparing two Great Depressions: 1929-33 to 1989-93” in Lessons from the Economic Transition: Central and Eastern Europe in the 1990s. Salvatore Zecchini, ed. Dordrecht: Kluwer, pp. 225-240.

Sabirianova, Klara. 2000. "The Great Human Capital Reallocation: A Study of Occupational Mobility in Transitional Russia," William Davidson Institute Working Paper 309.

Sachs, Jeffrey and Andrew Warner. 1996. "Achieving Rapid Growth in the Transition Economies of Central Europe," SITE Discussion Paper 116.

Schneider, Friedrich and Dominik Enste, 2000. "Shadow Economies: Size, Causes, and Consequences", J. Econ. Lit. 38:1, pp. 77-114.

Selowsky, Marcelo and Ricardo Martin. 1997. "Policy Performance and Output Growth in the Transition Economies," Amer. Econ. Rev. (Papers and Proceedings) 87: 2, pp. 349-53.

Shapiro, Judith. 1995. "The Russian Mortality Crisis and its Causes" in Russian Economic Reform at Risk. Anders Aslund, ed. London: Pinter. 
Stiglitz, Joseph. 1994. Whither Socialism? Cambridge: MIT Press.

Svejnar, Jan. 1999. "Labor Markets in Transitional Central and Eastern European Economies," in Handbook of Labor Economics, Vol 3b, Orley Ashenfelter and David Card, eds. Amsterdam: Elsevier, pp. 2810-2857.

Syrquin, Moshe. 1988. "Patterns of structural change," in Handbook of Development Economics: Vol. 1. Hollis Chenery and T.N. Srinivasan, eds. Amsterdam: Elsevier, pp. 203-273.

Temple, Jonathan. 1999. “The New Growth Evidence,” J. Econ. Lit. 37:1, pp. 112-56.

United Nations Development Program. 1998. Human Development Report, NY: Oxford U.Press [UNDP].

United Nations Development Program. 1998. Poverty in Transition? NY: Oxford U.Press, 1998.

UNICEF. 1999. After the Fall: The Human Impact of Ten Years of Transition. Florence: UNICEF.

Young, Alwyn. 2000. "The Razor's Edge: Distortions and Incremental Reform in the People's Republic of China," Quart. J. Econ. 115:4, pp 1091-1135.

Wolf, Holger. 1999. "Transition Strategies: Choices and Outcomes," Princeton Studies in International Finance 85.

World Bank. 1994. Governance: The World Bank's Experience. Washington DC: World Bank.

World Bank. 1996. Statistical Handbook: States of the Former USSR. Washington DC: World Bank.

World Bank. Various years. World Development Report [WDR]. Washington DC: World Bank.

World Bank. Various years. World Development Indicators [WDI]. Washington DC: World Bank.

Zettelmeyer, Jeromin. 1998. "The Uzbek Growth Puzzle," IMF Working Paper 98/133. 


\section{DAVIDSON INSTITUTE WORKING PAPER SERIES - Most Recent Papers}

The entire Working Paper Series may be downloaded free of charge at: www.wdi.bus.umich.edu

CURRENT AS 5/23/02

\begin{tabular}{|c|c|c|}
\hline Publication & Authors & Date \\
\hline $\begin{array}{l}\text { No. 470: Growth in Transition: What We Know, What We Don't, and } \\
\text { What We Should }\end{array}$ & $\begin{array}{l}\text { Nauro F. Campos and Fabrizio } \\
\text { Coricelli }\end{array}$ & Feb. 2002 \\
\hline $\begin{array}{l}\text { No. 469: Barriers to Investment by Russian Firms: Property Protection } \\
\text { or Credit Constraints? }\end{array}$ & Susan J. Linz & May 2002 \\
\hline No. 468: Job Satisfaction Among Russian Workers & Susan J. Linz & May 2002 \\
\hline $\begin{array}{l}\text { No. 467: Assessing the Problem of Human Capital Mismatch in } \\
\text { Transition Economies }\end{array}$ & $\begin{array}{l}\text { Viliam Druska, Byeong ju Jeong, } \\
\text { Michal Kejak, and Viatcheslav } \\
\text { Vinogradov }\end{array}$ & Mar. 2002 \\
\hline $\begin{array}{l}\text { No. 466: Motivating Russian Workers: Analysis of Age and Gender } \\
\text { Differences }\end{array}$ & Susan J. Linz & Feb. 2002 \\
\hline No. 465: Virtual Reality: Barter and Restructuring in Russian Industry & Gary Krueger and Susan J. Linz & Apr. 2001 \\
\hline $\begin{array}{l}\text { No. 464: Lending of Last Resort, Moral Hazard and Twin Crises: } \\
\text { Lessons from the Bulgarian Financial Crisis 1996/1997 }\end{array}$ & $\begin{array}{l}\text { Michael Berlemann, Kalin } \\
\text { Hristov and Nikolay Nenovsky }\end{array}$ & May 2002 \\
\hline $\begin{array}{l}\text { No. 463: Deindustrialisation. Lessons from the Structural Outcomes of } \\
\text { Post-Communist Transition }\end{array}$ & $\begin{array}{l}\text { Tomasz Mickiewicz and Anna } \\
\text { Zalewska }\end{array}$ & Jan. 2002 \\
\hline $\begin{array}{l}\text { No. 462: Joint Liability Lending and the Rise and Fall of China's } \\
\text { Township and Village Enterprises }\end{array}$ & Albert Park and Minggao Shen & July 2001 \\
\hline $\begin{array}{l}\text { No. 461: A Refinancing Model of Decentralization with Empirical } \\
\text { Evidence from China }\end{array}$ & Albert Park and Minggao Shen & Apr. 2002 \\
\hline $\begin{array}{l}\text { No. 460: The Effects of Market Liberalization on the Relative Earnings } \\
\text { of Chinese Women }\end{array}$ & $\begin{array}{l}\text { Margaret Maurer-Fazio and } \\
\text { James Hughes }\end{array}$ & Mar. 2002 \\
\hline $\begin{array}{l}\text { No. 459: The Role of Education in Determining Labor Market } \\
\text { Outcomes in Urban China's Transitional Labor Markets }\end{array}$ & Margaret Maurer-Fazio & Apr. 2002 \\
\hline $\begin{array}{l}\text { No. 458: Real and Monetary Convergence within the European Union } \\
\text { and Between the European Union and Candidate Countries: } \\
\text { A Rolling Cointegration Approach }\end{array}$ & $\begin{array}{l}\text { Josef C. Brada, Ali M. Kutan and } \\
\text { Su Zhou }\end{array}$ & Apr. 2002 \\
\hline No. 457: Credit Ratings as Coordination Mechanisms & $\begin{array}{l}\text { Arnoud W. A. Boot and Todd T. } \\
\text { Milbourn }\end{array}$ & Mar. 2002 \\
\hline $\begin{array}{l}\text { No. 456: Balkan and Mediterranean Candidates for European Union } \\
\text { Membership: The Convergence of their Monetary Policy with that of the } \\
\text { European Central Bank }\end{array}$ & Josef C. Brada and Ali M. Kutan & Apr. 2002 \\
\hline $\begin{array}{l}\text { No. 455: Russian Financial Transition: The Development of Institutions } \\
\text { and Markets for Growth }\end{array}$ & David M. Kemme & Oct. 2001 \\
\hline $\begin{array}{l}\text { No. 454: Does the Market Pay Off? Earnings Inequality and Returns to } \\
\text { Education in Urban China }\end{array}$ & Xiaogang $\mathrm{Wu}$ and $\mathrm{Yu} \mathrm{Xie}$ & Apr. 2002 \\
\hline $\begin{array}{l}\text { No. 453: Entrepreneurs' Access to Private Equity in China: } \\
\text { The Role of Social Capital }\end{array}$ & Bat Batjargal and Mannie M. Liu & Apr. 2002 \\
\hline $\begin{array}{l}\text { No. 452: The Determinants of Privatised Enterprise Performance in } \\
\text { Russia }\end{array}$ & $\begin{array}{l}\text { Alan A. Bevan, Saul Estrin, Boris } \\
\text { Kuznetsov, Mark E. Schaffer, } \\
\text { Manuela Angelucci, Julian } \\
\text { Fennema and Giovanni } \\
\text { Mangiarotti }\end{array}$ & June 2001 \\
\hline $\begin{array}{l}\text { No. 451: Determinants of Financial Distress: What Drives Bankruptcy } \\
\text { in a Transition Economy? The Czech Republic Case }\end{array}$ & Lubomír Lízal & Jan. 2002 \\
\hline No. 450: Corporate Governance and the Global Social Void & Lee A. Tavis & Oct. 2001 \\
\hline $\begin{array}{l}\text { No. 449: Financial Architecture and Economic Performance: } \\
\text { International Evidence }\end{array}$ & Solomon Tadesse & Aug. 2001 \\
\hline $\begin{array}{l}\text { No. 448: Growth Slowdown Under Central Planning: A Model of Poor } \\
\text { Incentives }\end{array}$ & Zuzana Brixiová and Aleš Bulír & Mar. 2002 \\
\hline $\begin{array}{l}\text { No. 447: Dis entangling Treatment Effects of Polish Active Labor } \\
\text { Market Policies: Evidence from Matched Samples }\end{array}$ & $\begin{array}{l}\text { Jochen Kluve, Hartmut Lehmann, } \\
\text { and Christoph M. Schmidt }\end{array}$ & Jan. 2002 \\
\hline
\end{tabular}

